\title{
Keelekasutusmustrid verbist paremal: morfosüntaktiline ja leksikaalsemantiline varieerumine
}

\author{
PILLE ESLON \\ Tallinna Ülikool
}

Ülevaade. Artiklis kirjeldatakse eesti ilukirjanduskeele kasutusmustreid verbi paremkontekstis. Vaatluse all on kolmest komponendist koosnevad adverbi sisaldavad ja adverbita struktuurid. Adverbi sisaldavate struktuuride alusel kujuneb nii vabadest ja seotud kui ka ainult seotud laienditest liitseid leksikaalgrammatilisi üksuseid - analüütilisi partikleid (nt ju ja $k a$ tõmbumine semantilis-süntaktiliseks ja fonoloogiliseks tervikuks ei ole ju ka endine), sidendeid (nt rinnastav-alistavad rühmsidendid mitte ainult (enam üldse / nii palju) .., vaid (kui) möönduse väljendamisel), vorme (nt mineviku liitaja vormid), analüütilisi sõnu (nt liitsõnad, ühendverbid) ja analüütilisi konstruktsioone (nt ahelverbid, liitsed verbitarindid). Seevastu adverbita struktuure iseloomustab kollokatiivsus ja idiomaatilisus (nt terane tüdruk, võóras veri, ka väljendverbid). Tegu on kahe eesti keele kasutusele iseloomuliku tendentsiga, millest esimene peegeldab aglutinatiivse mudeli põhimõtet - morfeemide või lekseemide liitumist (grammatisatsiooni ja leksikaliseerumisega seotud protsessid), teine leksikaalsemantilisi piiranguid mitmesõnaliste üksuste moodustumisel. Verbi paremkonteksti mustritel on kindlad tekstilised funktsioonid, mille aluseks fikseeritud sõnajärjega struktuuride morfosüntaktilised ja leksikaalsemantilised piirangud. Tegelikud seosed struktuuri komponentide vahel ehk kasutusreeglid on seda kitsamad, mida vabamana keele toimimist on harjutud käsitlema. Selles aspektis on eesti keele n-ö vaba sõnajärje korrastamisel ja tekstiloomes 
tervikuna oluline osa adverbi sisaldavatel struktuuridel ja analüütilistel üksustel. Struktuuri komponentide kinnistumine mingis kindlas tekstifunktsioonis kujundab keelekasutusmustreid ning avab võimalusi stereotüüpseks kasutamiseks (nt toimus sel aastal, oli sel suvel; on kord juba, tuleb kord jälle).

Märksõnad: semantika; morfosüntaks; keelekasutusmustrid; eesti keel

\section{Uurimisobjekt, eesmärk, meetodid}

Eesti ilukirjanduskeele kasutusmustreid on kirjeldanud Jekaterina Trainis ja Kais Allkivi (2014). Oma varasemates uurimustes olen sama keelematerjali põhjal analüüsinud verbi vasakkonteksti, eraldi olen käsitlenud adverbe sisaldavaid struktuure ja vaadelnud nende tekstifunktsioone (nt Eslon 2013; 2014b). Võrdlusest eesti õppijakeelega on selgunud, et õppija väldib adverbe sisaldavaid struktuure ega kasuta neid sarnaselt emakeelekõnelejaga. Samas on adverbiga struktuurid analüütiliste üksuste moodustumise alus. (Vt Eslon 2014a; Allkivi 2016a) Samatähenduslike sünteetiliste ja analüütiliste verbide tekstikasutusmustrid langevad eesti ilu- ja ajakirjanduskeele analüüsi põhjal harva kokku (vt Eslon \& Paeoja 2015: 96-99).

Käesoleva artikli uurimisobjekt on sagedad sõnaliigijärjendid ehk morfosüntaktilised struktuurid verbist paremal. Eesmärk on need leida, lingvistiliselt seletada ja kirjeldada, tuues esile struktuuride avara morfosüntaktilise ja leksikaalsemantilise varieerumise, kinnistunud koosluste ja stereotüüpsete nähtuste vahelised seosed. Huvi pakuvad järgmised küsimused: 1) millised morfosüntaktilised struktuurid on keeleomased verbist paremal, kas samuti adverbi sisaldavad, nagu verbi vasakkontekstis; 2) milliseid tendentse esineb struktuuride morfosüntaktilises, semantilises ja funktsionaalses varieerumises ning kinnistumises, kuidas mõjutavad neid protsesse piirangud; 3) millega võiks seletada struktuuri komponentide stereotüüpset kasutamist ning stereotüüpide kujunemist. 
Vastuste saamiseks analüüsisin Klastrileidjaga ${ }^{1}$ ilukirjanduskeele morfosüntaktiliselt märgendatud tekste (maht ligi 200000 sõnet), sama keelematerjali on kasutatud ka eespool viidatud uurimustes. Andmekaeve põhimõttel töötava Klastrileidja seadistasin trigramme otsima. Analüsaator leidis üldvalimist 37448 trigrammi, millest ainukordseid oli 23 264, viis ja enam korda esines 5378 trigrammi. Siinse lingvistilise analüüsi objektiks on V-algulise morfoloogilise klassi trigrammid ehk kõik verbiga algavad trigrammid. Neid on kokku 695 (13\% viis ja enam korda esinenud trigrammidest), mis lõpukomponendi sõnaliigi järgi jagunevad seitsme morfoloogilise alamklassi vahel: V-D 59\%, V-S 21\%, V-A 12\%, V-K 4\%, V-V 2\%, V-P 1\%, V-J 1\%. ${ }^{2}$

Tekstikasutuses olulised verbialgulised morfoloogilised alamklassid lõpevad adverbi (V-D), substantiivi ( $\mathrm{V}-\mathrm{S})$ ja adjektiiviga $(\mathrm{V}-\mathrm{A})$. Trigrammi keskmise komponendi sõnaliigi varieerumise alusel eristub alamklassis V-D neli morfoloogilist klastrit (varieeruvad adverb, verb, substantiiv ja pronoomen: vastavalt VDD 27\%, VVD 15\%, VSD 11\% ja VPD 9\%). Poole väiksema esinemusega alamklassi V-S klastrite varieerumine on järjendi võrra avaram (keskmine komponent on adjektiiv, adverb, pronoomen, verb ja substantiiv: vastavalt VAS 9\%, VDS 6\%, VPS 3\%, VVS 1\% ja VSS 1\%). Alamklass V-A koosneb ühest klastrist (adverbi sisaldav VDA 13\%), nagu ka alamklassid V-K (substantiivi sisaldav VSK 4\%) ja V-J (adjektiivi sisaldav VAJ 1\%). Kõigis alamklassides on komponentidel piiratud distributiivsed omadused, mis näitab keelekasutaja eelistusi sõnaliikide kombineerimisel tekstis.

Edasi kirjeldan kolmest komponendist koosnevate sõnaliigijärjendite morfosüntaktilise, leksikaalsemantilise ja funktsionaalse

\footnotetext{
Veebiliides aadressil http://evkk.tlu.ee/Search/search_reeglid.html (11.1.2016).

2 Klastrileidjaga esile toodud sõnaliigijärjendite rühmitamise ja kirjeldamise aluseks on keelestruktuuride hierarhia - morfoloogiline klass $>$ alamklass $>$ klaster $>$ morfosüntaktilised n-grammid -, mis tugineb programmi tööpõhimõtetele ja morfosüntaktiliste märgendite formalismile (täpsemalt vt Trainis \& Allkivi 2014: 284; Trainis 2015: 233-239; Allkivi 2016b: 62). Seetõttu pole siinses ega nimetatud autorite samalaadsetes uurimustes mõisteid morfoloogiline klass ja sõnaliik kasutatud sünonüümselt. Morfoloogiline klass ei kattu ka Huno Rätsepa (1978: 39) sõnaklassi mõistega.
} 
varieerumise piire ning vaatlen struktuuri komponentide vahelistest seostest tulenevaid kasutuspiiranguid.

\section{Analüüsi tulemused}

Kuna eesti ilukirjanduskeele kasutusmustrites verbist paremal on adverbi sisaldavate struktuuride esinemus adverbita struktuuridest tunduvalt suurem (vastavalt $81 \%$ ja 19\%), siis võtsin selle arvtunnuse nende esmase liigenduse aluseks: 1 . adverbi sisaldavad mustrid (VDD, VVD, VDS, VDA, VSD, VPD) ja 2. adverbita mustrid (VAS, VPS, VVS, VSK, VAJ, VSS).

Teine mustrite klassifitseerimise tunnus on morfosüntaktilise varieerumise piirid. Selle põhjal võib struktuuridel olla kas üks kindel ehk piiratud vormistus või on sama struktuuri raames näha grammatiliste vormide avaramat kasutust. Nii jagunevad adverbe sisaldavad struktuurid omakorda kaheks: 1.1. verbi avara (VDD) või piiratud (VDA, VVD) varieerumisega ning 1.2. struktuuri kõigi komponentide avara (VDS) või piiratud (VSD, VPD) varieerumisega mustrid. Adverbita struktuuride morfosüntaktiline varieerumine hõlmab kõiki komponente: 2.1. avara (VAS, VPS, VVS) või 2.2. piiratud varieerumisega (VSK, VAJ, VSS) mustrid.

Kolmas tunnus on mustri leksikaalsemantiline ja funktsionaalne varieerumine, mille avab iga struktuuri trigrammide üksikasjalik kirjeldus. Sellest liigendusest lähtuvad ka analüüsipeatüki alljaotised.

\section{Adverbi sisaldavad mustrid}

1.1. Verbi avar morfosüntaktiline varieerumine leksikaalsemantiliselt ja funktsionaalselt piiratud adverbikooslused

Niisuguste struktuuride omapära on seotud kahe nähtusega: a) verb on leksikaalsemantiliselt piiratud, kuid morfosüntaktiliselt varieeruv; b) kasutatakse kinnistunud adverbikooslusi, sh kollokatiivseid ja idiomaatilisi, millel on erinevaid tekstifunktsioone. Neile tingimustele vastab järjend verb-adverb-adverb ehk VDD-struktuur, mille 
esinemus verbi paremkontekstis on kõige suurem (27\%). Selle mustri morfosüntaktiline varieerumine piirdub verbi grammatiliste vormidega, mille alusel VDD-struktuuriga trigrammid jagunevad üheksasse rühma (reastatud sageduse järgi):

1) IND:IMPERF:SG:3 ehk kindla kõneviisi lihtmineviku ainsuse 3. pööre (läks peagi laiali, pöörles üha kiiremini, ütles peaaegu sosinal, oli üsna kõrgelt <üle lennanud>, sai liiga palju, kavatses kuhugi ära <sõita>) - 62 näidet;

2) IND:PRES:SG:3 ehk kindla kõneviisi oleviku ainsuse 3. pööre (vaatab otsivalt ringi, on nii selgesti <nähtav>, tuleb ehk ka, langeb täielikult ära) - 47 näidet;

3) IND:NEG:IMPERF ehk kindla kõneviisi lihtminevik eitavas kõnes (polnud kunagi varem, <ei> olnud ikka veel) - 18 näidet;

4) IND:IMPERF:PL:3 ehk kindla kõneviisi lihtmineviku mitmuse 3. pööre (sööstsid nii ruttu) - 7 näidet

5) IND:NEG:PRES ehk kindla kõneviisi olevik eitavas kõnes (pole juba ammu <näinud >, <ei> juhtu üldse midagi) - 7 näidet;

6) COND:PRES:SG:3 ehk tingiva kõneviisi oleviku ainsuse 3. pööre (oleks ka juba) - 5 näidet;

7) IND:IMPERF:PL:1 ehk kindla kõneviisi lihtmineviku mitmuse 1. pööre (elasime seal pahaaimamatult) - 5 näidet;

8) IND:PRES:PL:3 ehk kindla kõneviisi oleviku mitmuse 3. pööre (on ju veel $<$ noorukesed $>$ ) -5 näidet;

9) INF ehk infiniitne vorm (da-tegevusnimi) (elada nii omaette) 5 näidet.

Tekstikasutuses on tavaline nii finiitöeldis kindla kõneviisi lihtmineviku (harvem oleviku) ainsuse (harvem mitmuse) 3. pöörde vormis kui ka olema-verb abiverbi funktsioonis (mineviku liitajavormides, harvem koopulana). Eitavas kõnes on samuti sagedam lihtmineviku vorm, olevik esineb harva. Statistiliselt eristuvad vormivastandused on kindel $v s$. tingiv kõneviis (156 vs. 5 näidet), 3. vs. 1. pööre (126 vs. 5), ainsus vs. mitmus (114 vs. 17). Kuna verbi mitmuse vormid jävad ainsusele sageduse poolest selgelt alla, siis kirjeldan neid koos lihtmineviku ja oleviku 
ajavormidega; samuti toimin eitava kõnega. Mõte on leida seoseid verbi leksikaalsemantiliste ja morfosüntaktiliste piirangute ning järjestikku paiknevate adverbide tekstikasutuse vahel.

\subsubsection{IND:IMPERF:SG(PL):3}

Lihtmineviku vormis verbide valik piirdub nelja leksikaalsemantilise rühmaga: a) olema ennemineviku liitajavormis (IMPERF:SG:3, nt oli juba ära <läinud>, oli niivorrd hästi < tehtud>), samuti koopula funktsioonis (IMPERF:PL:3, nt olid küll lahti) ning eksisteerima (IMPERF:PL:3) finiitöeldisena (nt eksisteerisid samuti täiesti); b) liikumisverbid minema ja tulema (IMPERF:SG:3) tavaliselt otsetähenduses (nt läks esiteks viisakalt $<$ rääkima>, ühendverb tuli jälle tagasi), harvem ülekantud tähenduses (nt väljendverb läks kõige rohkem <hinge>); c) mõttetegevust tähistavad verbid (IMPERF:SG:3) liitpredikaadis da-infinitiiviga (kavatses/ mõtles/otsustas/mõistis/püüdis nii vähemalt teha); d) tegevusverbid (IMPERF:SG(PL).3) finiitöeldisena: manööverdas, küürutas, kakerdas, pöorles, kadus, juhtus, roomas ja sööstsid, tõusid.

Verbi leksikaalsemantiliste piirangute, nende vormi ja funktsiooni varieerumisega kaasnevad seaduspärasused adverbide tekstikasutuses.

1) Kui verbi kasutatakse abiverbi funktsioonis, siis on järjestikustel adverbidel soodumus tõmbuda semantilis-süntaktiliseks ja fonoloogiliseks tervikuks. Tuleb ette analüütilisi vorme (nt ülivõrre oli kõige rohkem käinud ja ilma näinud) ja kujunemisjärgus analüütilisi sõnu (potentsiaalsed liitadverbid nagu oli jälle kord ennast tõestanud, oli vaid veidi eemale läinud, oli niivorrd hästi ette valmistatud, et), mis iseloomustavad verbi vasakkontekstis paiknevat tegijat, seisundipassiivi puhul subjekti ( $\underline{\text { ta }}$ oli jälle kord ennast tõestanud; ta oli niivorrd hästi ette valmistatud). Nagu saksa nii ka eesti keeles kasutatakse verbi liitaja ja analüütilise verbivormi komponentide vahel mitut määruslikku laiendit, sh rõhumäärsõnu (k.a subjektiivmodaalsed hinnangusõnad) ja verbipartikleid (afiksaaladverbid), nt oli üsna kôrgelt puu otsast alla sadanud - oli alla sadanud kust? 
(puu otsast - kaassõnafraas, kohamäärus; kõrgelt puu otsast - määr + koht), oli alla sadanud kui kõrgelt? (üsna kõrgelt - määra subjektiivmodaalne hinnang).

Sarnaste adverbikoosluste esimene komponent on tavaliselt rõhumäärsõna, mis laiendab järgnevat määrust ja intensiivistab (harvem pehmendab) selle tähendust (<tuli > soojendas nii mõnusalt, oli ju rängalt <viga saanud>, <võll> pöörles üha kiiremini; sööstsid nii ruttu, olid küll lahti). Rõhusõna ja määruslik laiend tõmbuvad semantilis-süntaktiliseks ning fonoloogiliseks tervikuks (<ta> hõikas veel kord, <auto> kihutas üha kiiremini), kirjeldades tegevust, selle toimumise viisi ja laadi. Korduvalt kasutatud rõhusõnad siiski, ehk, pigem, kuidagi, liiga täpsustavad koos järgneva adverbiga tegevuse määra, nt pigem veelgi/siiski/absoluutselt/ kuidagi poolikult/teadlikult/liiga palju. Paralleelselt leidub vastupidiseid näiteid, kus rõhusõnad nii ja veel on viisi- ja ajamääruse funktsioonis, iseloomustades subjekti tegevust ( $t a$ pü̈̈dis nii 'sel moel, viisil' vähemalt kuidagi aidata; tööandja otsustas veel 'esialgu' mitte ära öelda). Teksti autori valikud ja lugeja tõlgendused sõltuvad kontekstist.

VDD-struktuuri viimane komponent võib olla nii järgnevasse paremkonteksti kuuluv verbipartikkel ära (ta kavatses kuhugi ära sõita), rõhusõna $k a$, mille abil aktualiseeritakse järgneva konteksti sisu (ópetaja mõistis täielikult ka meie pü̈üllusi) ja käitub seega partiklina, samuti ajamäärus veel mitte, mis iseloomustab põhiverbi tegevust (Mart otsustas veel mitte lahkuda ehk otsustas mitte veel lahkuda) jm.

2) Liikumist ja mõttetegevust tähistavatele verbidele ning tegevusverbidele järgnev adverb kuulub tavaliselt verbipartiklite hulka. Moodustub hulk ühendverbe, mille komponente eraldavad enamasti viisi- ja ajamäärused, nt läks peagi laiali, läks omasoodu edasi, küürutas kähku maha, andis niivõrd järele, pidas väga kinni, pressis $i k k a$ läbi, surus julmalt maha, tuli jälle tagasi, vaatas otsivalt ringi, sai ruttu otsa, segas siis vahele. 


\subsubsection{IND:PRES:SG(PL):3}

Pool selle rühma näidetest on finiitöeldisega: kasutatakse erinevaid täistähenduslikke verbe kindla kõneviisi oleviku ainsuse 3. pöördes (naeratab, kõlab, põhineb, paistab, langeb, kostab, piirab). Nende seas eristub sageduse poolest rühm tajuverbe (nt paistab, kostab, kõlab), mis on tavaliselt ühend- või väljendverbide põhiverbiks (paistab vahel juba ära, paistab nüüd juba <kätte>). Järgnevad ajamäärused nü̈̈d ja vahel, mis sobivad semantiliselt tajuverbidega (kostab nü̈̈d päris hästi, kõlab vahel veidi naljakalt).

Teine pool näidetest sisaldab olema-verbi kindla kõneviisi oleviku ainsuse 3. pöördes abiverbi funktsioonis: täismineviku liitajavorm (on sinna juhuslikult < sattunud $>$, on hoopis teistmoodi $<$ tehtud $>$ ), harvem koopula (on ju üsna <tõenäoline>, <nad > on ju veel <väikesed $>$, on $j u$ ainult $<$ kooliealised $>$ ). Liitaja ning liitpredikaadi komponentide vahele jääb tavaliselt kaks adverbi. Üksikjuhtumitel esinevad kindla kõneviisi oleviku ainsuse 3. pöördes ka modaalne abiverb saab ja liikumist või selle algust tähistavad verbid tuleb, hakkab ja algab.

Verbi kooskasutuses järgnevate adverbidega tulid esile järgmised seaduspärasused:

1) Adverbide valik ja kombineerimisvõimalused on verbi semantikast mõjutatud: a) kui verb on otsetähenduses, rõhutab järgnev adverbikooslus tegevuse määra ja kirjeldab seeläbi subjekti (lugema $-<$ ta $>$ loeb üldse liiga <vähe>), ning kui ülekantud tähenduses, siis sündmuse ebaolulisust (<see ettevaatusabinõu > loeb üldse liiga <vähe> 'ei oma tähtsust'); b) kui ühendverb on otsetähenduses, siis on selle komponente lahutav adverb tavaliselt viisimäärus (ringi vaatama 'mitmes suunas vaatama' - vaatab otsivalt/hirmunult/ehmunult/ kõhklevalt/pingsalt ringi), ülekantud tähenduses 'järele kuulama, otsima’ aga kohamäärus (vaatab ümberkaudu/linnas ringi). Esimeses näites on samal adverbikooslusel erinevad pragmaatilised, teises erinevad süntaktilised funktsioonid. 
2) Finiitöeldisele järgnevad kinnistunud tekstifunktsiooniga adverbikooslused (vt ka punkt 1.1.1). Korduvalt kasutatakse järgmisi kombinatsioone: a) rõhumäärsõna $k a$ koos ajamäärustega varem ja hiljem (saab $\mathrm{ka}$ varem/hiljem <tulla>) - edastab pragmaatilist tähendust 'pole kohustuslik täpselt ette nähtud ajaks tulla', 'võib, on lubatud tulla ettenähtud ajast varem või hiljem’; b) harvem kohamäärus ümberringi koos piiritletuse markeriga ainult 'vaid' (piirab ümberringi ainult $<$ mets $>$ ) - leksikaalsemantiline vastandus piiritlematuse (ümberringi) ja piiritletuse (ainult 'vaid') vahel loob kujutluspildi ümberringi laiuvast metsast, tõstes selle tähelepanu keskmesse; c) intensiivistavad rõhumäärsõnad (üle)üldse ja liiga (loeb üldse liiga <vähe, palju>, teeb üldse liiga <suuri järeldusi>) koos järgnevate kvantiteedi- ehk hulga- ja määrasõnadega; d) verbi laiendavad subjektiivmodaalsed hinnangusõnad koos rõhupartiklitega ka ja ju (tuleb ehk ka, põhineb ju vist), mis pehmendavad arvamuse kategoorilisust ja rõhutavad autori möönvat suhtumist kõnesolevasse. Ka see on pragmaatilise tähenduse näide. Kirjeldatud juhtumitel on nii $k a$ ja ju kui ka ainult partiklid, mis tõmbuvad semantiliselt järgneva adverbiga, võimaldades edastada erinevaid pragmaatilisi tähendusi, sh möönvat suhtumist kõnesolevasse: tuleb ehk ka - mööndus, kahtluse väljendamine, millegi võimalikuks pidamine; põhineb ju vist - mööndus, kahtlus. Sama käib mõningate koopula ja predikatiivi vahel esinevate adverbikoosluste kohta, nt $<$ nad $>$ on ju veel $<$ väikesed $>$, on ju ainult $<$ kooliealised $>$, <lapsed $>$ on juba nii < vanad küll, et ..>.

3) Liitajavormis (täisminevik) järgnevad abiverbile erinevad rõhumäärsõnad. Subjektiivmodaalsete hinnangusõnadega tõesti, täielikult, peaaegu, vist, võib-olla mõõdetakse informatsiooni tõeväärtust; ju, juba, veel, kord, just, ikka, siiski, kah toovad esile sündmuse erinevaid aspekte, nt on ju ammuilma - aktualiseeritakse tõdemust, lisandub tugev ekspressiivne varjund.

Olgugi et subjektiivmodaalsete hinnangusõnade ja ülejäänud rõhumäärsõnade omavaheline kombineerimine on üldjuhul varieeruv, kasutatakse umbes kolmandikus näidetest siiski niisugust 
adverbikooslust, kus subjektiivmodaalsele hinnangusõnale järgneb tavaliselt viisi- (lt-lõpulised stereofooniliselt, aktiivselt), aja- (hiljaaegu, praegu, nüüdki, ammuilma) või kohamäärus (kaugelt). Semantiliste terviküksuste kujunemist nende koosluste alusel mõjutavad siin enim verbile järgnevad rõhupartiklid $j u$, nii ja hoopis kasutatuna koos viisimäärusega (on hoopis teistmoodi <tehtud>, on ju samamoodi <värvitud $>$ ). Ka analüütiliste verbide puhul eraldab abiverbi ja verbipartiklit rõhumäärsõna, harvem määrasõna (on tublisti edasi $<$ arenenud $>$, on ju läbi lugenud>, on salaja maha <maetud>). Ülejäänud näidetes seostuvad omavahel tihedamini kaks subjektiivmodaalset hinnangusõna (on tõesti täiest $i<$ kadunud $>$, on vist tõesti) või hinnangusõna koos rõhumäärsõnaga, mis kõnesolevat intensiivistab või pehmendab (on vist alles, on juba päris).

Üldistuste sõnastamisel korratakse sageli paari leksikaalselt piiratud VDD-järjendit: on kord juba/jälle) ja tuleb kord jälle (elu on kord juba selline, ühiskond on kord juba niimoodi seatud; Islandi tuhk tuleb kord jälle jne). Tegu on tekstiloomele omase leksikaalgrammatilise stereotüübiga, mida tavaliselt kasutatakse selleks, et toonitada mingi nähtuse paratamatust.

\subsubsection{Neg.IMPERF ja PRES}

Eituse väljendamiseks on lihtminevikus ja olevikus kaks võimalust: a) polnud (harva pole, ei ole), nt polnud seal ka, polnud mitte ainult, polnudki nii palju, polnud ka enam ning pole lihtsalt nii <palju aega, et ..>, pole ju ka <kusagilt abi oodata $>$, ja b) eituspartikkel verbi vasakkontekstis, nt <ei> laienenud ka kaugeltki, <ei > vaielnud kunagi vastu, <ei> vajunud eest nii ning <ei> juhtu üldse mitte <niisama/põhjuseta $>$, <ei> kao ka siis <ära, kui ..>, <ei> toimu praegu mitte <midagi peremehe teadmata $>$. Lühivormid polnud (pole) ja harva kasutatud ei ole kuuluvad liitajavormi: pole juba ammu <näinud/kohtunud>, polnud veel ära $<$ sõitnud $>$, polnud küll päriselt < omandanud $>$, polnud küll kunagi < $<$ näinud $>$; $<$ ei $>$ ole ju $k a<$ nemad seal käinud ega olukorraga tutvunud $>$. 
Eitusele järgnevad adverbid moodustavad leksikaalgrammatilisi terviküksuseid, mille kasutamine assotsieerub emakeelekõnelejal piiratud hulga kontekstidega.

1) Adverbikooslused kuuluvad vastandava rinnastuse a) mitte $X$, vaid $Y$-tüüpi rühmsidendisse, edastades möönduse tähendust, nt polnud mitte ainult lapsed, vaid ka täiskasvanud (mitte ainult .. vaid ka); polnud enam üldse lapsed, vaid päris täiskasvanud (enam üldse .. vaid); polnudki nii palju osavõtjaid, kui arvata võis (nii palju .. kui) - soov sündmust möönvalt esile tuua ja hinnata, või b) polnud küll kunagi ja polnud küll päriselt tarindisse, millele järgnev osalause algab rinnastavate sidesõnadega aga, kuid, ent, nt Ta polnud küll kunagi saanud mingit muusikaalast ópetust, agalkuid ..; eilne meeleolu polnud küll päriselt kadunud, kuid/ent .. Rühmsidendisse kuuluval adverbikooslusel on mitu funktsiooni: grammatiline, osalauseid siduv ja rõhufunktsioon.

2) Kaks sageli koos esinevat rõhumäärsõna enam üldse ja ka kaugeltki (mitte) käituvad tekstikasutuses kui analüütilised partiklid, toonitades eitust ning rõhutades kõnesoleva mittevastavust tegelikkusele $(e i$ olnud enam üldse huvitatud, ei laienenud ka kaugeltki kõigile osalistele). Tavaliselt sulanduvad analüütilisteks partikliteks kaks järjestikust partiklit, nt <ei> ole ju ka <nemad seal käinud ega olukorraga tutvunud $>$, pole ju ka <kusagilt abi oodata $>$, <ei $>$ juhtu üldse mitte $<$ niisama, põhjuseta $>$ - neid kasutatakse möönduse väljendamiseks, soovist vaikimisi õigustada, põhjendada. Niisugused adverbikooslused sisaldavad sageli rõhumäärsõnu nii, mitte, $k a$, veel, enam, ikka ja küll, nt <ei> ole küll mitte, polnud nii enam <juhtunud>. Koos kasutatuna täpsustavad need verbi paremkonteksti pragmaatikat ja semantikat.

Terviküksusi moodustab ka rõhumäärsõna koos järgneva määrusega, tekstis on sagedad partiklina kasutatud juba + ajamäärus ammu (pole juba ammu <näinud, kohtunud>); patikkel $k a+$ ajamäärus siis (<ei> kao ka siis <ära, kui ..>); ajamäärus praegu + eituspartikkel mitte (<ei $>$ toimu praegu mitte $<$ kui midagi peremehe 
teadmata $>$ ). Ka neid järjendeid kasutatakse pragmaatiliste ja ekspressiivsete tähendusvarjundite edastamiseks.

3) Analoogselt jaatava kõnega (sõitis kuhugile ära, oli kuhugile ära sõitnud; vaatab hoolikalt üle, vt eespool) moodustub ka eitava kõne VDD-struktuuri alusel analüütilisi verbe (<ta ei $>$ vaielnud kunagi vastu, polnud veel ära <sõitnud>, polnudki veel katki <läinud>). See on tüüpiline analüütiliste verbide kasutusmuster verbi paremkontekstis, kus põhiverbi ja verbipartiklit lahutavad üks või mitu adverbi. Põhiverb võib paikneda nii struktuuri alguses kui ka järgnevas paremkontekstis (<ta ei $>$ vaielnud kunagi vastu; polnud veel ära <sõitnud $>$ ).

Niisiis tuleb eitava kõne VDD-struktuuris esile järjestikuseid adverbe, mida jaatavas kõnes ei olnud: a) rühmsidendi kohustuslik semantilis-süntaktiline komponent möönduse väljendamisel, nt mitte ainult .. vaid $k a,<$ pole $>$ enam üldse .. vaid, <mitte> nii palju .. kui ja polnud küll kunagi .. aga/kuid/ent, polnud küll päriselt .. agal kuid/ent; b) analüütilised ehk liitpartiklid, nt (pole/ei ole) ju ka, juba ammu, ka siis, praegu mitte. See kajastab keele loomulikku varieerumist - mingis kindlas struktuuris kooskasutatud adverbid hakkavad samastuma funktsionaalselt ja fonoloogiliselt. Analoogselt potentsiaalsete liitadverbide kujunemisega jaatavas kõnes tulevad eitava kõne alusel esile rühmsidendid ja potentsiaalsed liitpartiklid.

\subsubsection{Verbivormi varieerumise marginaalsed juhtumid}

VDD-struktuuri vormivarieerumise marginaalsetest juhtumitest on viis seotud kõneviisi, viis pöörde- ja viis infiniitvormiga.

Kõneviisi varieerumine piirdub tingiva kõneviisiga (olema COND:PRES:SG:3 liitajavormi abiverbina), nt oleks ju $k a<$ tulnud $>$, oleks ka juba <tahtnud>, oleks juba äärepealt <käe sirutanud>, oleks kohe kõikjale <laienenud>. Kahe järjestikuse adverbi vahel toimivad samad üleminekud, mida eespool kirjeldasin: partiklistumine (partikli funktsioonis $k a, j u, j u b a$ ) laieneb trigrammi teiselt komponendilt kolmandale. 
Lisaks 3. pöörde ainsuse ja mitmuse vormide varieerumisele (vt eespool) kasutatakse haruharva ka mitmuse 1. pöörde vormi (elasime seal pahaaimamatult, elasime neljakesi koos, naersime millegipärast palju, läksime millegipärast öösel, käisime palju jala). Verbid kuuluvad erinevatesse semantilistesse rühmadesse, nende üldine kasutussagedus on suur (liikumisverbid käima, minema, eksistentsiaalverb elama, emotsiooniverb naerma). Verbile järgnevad erinevad määrused (põhjusmäärus millegipärast, kohamäärus seal, hulgamäärus neljakesi, viisimäärus pahaaimamatult, ajamäärus öösel ja kvantor palju). Leidub ka näide väljendverbi moodustumisest substantiivi kinnistunud käändevormiga: käisime jala (sUB:SG:GEN) > käisime jalgsi (ADV).

Viimane verbivormi marginaalse varieerumise juhtum on seotud predikatiivse da-infinitiiviga (liikumisverb minna, k.a analüütilises verbis välja minna, ainukordselt eksistentsiaalverb elada ja kõneverb mainida). Struktuuri teise komponendina on sagedam rõhusõna ainult (ühel korral ka nii ja hoopis). Kolmas komponent on pigem määruse funktsioonis (ajamäärus õhtuti, viisimäärus omaette), ent võib olla ka verbipartikkel välja või partikkel kõige, nt minna ainult õhtuti, minna hoopis välja, elada nii omaette, mainida ainult kõige. Kui esimene on rõhupartikkel, siis markeerib see järgnevat määrust; kui tegu on analüütilise verbiga, siis iseloomustab see leksikaalne komponent kirjeldatavat sündmust või alternatiivset tegevust (<või > minna hoopis välja; suhelda inimestega, mitte <kodus istuda>); kui koos on kaks rõhusõna-partiklit, siis on infinitiivi laiendiks objekt (mainida ainult kõige <paremaid töötajaid $>$ ). Seega ka verbi marginaalse varieerumisega seotud näidetes esineb VDD-struktuuri komponentidel kindlaid morfosüntaktilisi kombinatsioone, mis mõjutavad adverbi funktsioone. 
1.2. Verbi piiratud morfosüntaktiline varieerumine leksikaalsemantiliselt ja funktsionaalselt piiratud/kinnistunud adverbivalik

Leksikaalsemantiliselt ja funktsionaalselt piiratud/kinnistunud adverbivalik iseloomustab kahte piiratud morfosüntaktilise varieerumisega struktuuri: VDA (78 näidet) ja VVD (82 näidet).

\subsubsection{Verb-adverb-adjektiiv ehk VDA}

VDA-struktuuris on verb tavaliselt lihtmineviku või oleviku ainsuse 3. pöördes (IMPERF või PRES:SG:3, vastavalt 39 ja 31 näidet), harva lihtmineviku mitmuse 3. pöördes (IMPERF:PL:3, 8 näidet). Vormisageduspiirangutega käib kaasas vähene leksikaalne varieerumine: a) koopula funktsioonis on tüüpiliselt olema IMPERF või PREs:SG:3 (oli nii vali, on nii selge); b) finiitöeldisena üksikud ainukordsed täistähenduslikud verbid IMPERF:SG:3 (õitses laiguti kollane < võilill >, lehvis jälle punane <lipp >, seisis endiselt kole $<$ majalobudik $>,<\mathrm{udu}>$ paistis ('näima, tunduma') nii tihe $<$ olevat>, < kõik> tundus nii värske) või IND:PREs:SG:3 vormis (<õhtuks> vajub jälle paks <udu maha $>$, avaneb sootuks uus $<$ vaade $>$ ). Adjektiiv on reeglina predikatiivi funktsioonis (55 näidet), harvem eestäiend.

Adverb markeerib tavaliselt adjektiiviga väljendatud omaduse määra (oli väga raske, oli niivorrd habras, oli oige raske, oli pisut hale; on väga sarnane, on lausa pöörane, on liiga aus, on eriti raske), moodustades semantilisi määraskaalasid: väga > niivorrd > täiesti > üsna 'üleni' > pisut; väga > eriti > liiga > lausa $>$ küllalt; väga $>$ päris $>$ pigem; väga $>$ päris > peaaegu; väga $>$ täiesti $>$ täis $>$ peaaegu. Harvem tähistab adverb omaduse ilmnemise viisi (eriti lt-lópulised adverbid, nagu häirivalt, talumatult, mõnusalt, kiuslikult, hommikuselt, mänglevalt, lihtsalt, ebaloomulikult) või tõeväärtust hinnanguskaalal tõepoolest $>$ muidugi $>$ peaaegu $>$ vist. Omaduse rõhutatud esiletoomiseks kasutatakse partikleid nii(gi), ju, küll, eriti.

VDA-struktuuril on kaks sõnajärjemalli. Olenevalt predikaadi tüübist ja adjektiivi funktsioonist võib subjekt paikneda kas vasak- (olema 
finiitvorm + adverb + predikatiivne adjektiiv) või paremkontekstis (olema finiitvorm + adverb + adjektiiv eestäiendina), nt $<$ otsus $>$ oli väga raske ja oli väga raske <otsus $>$.

Kui verb on PREs:SG:3 vormis, siis markeerivad adverb ja adjektiiv vasakkontekstis paiknevat subjekti (<tõenäosus $>$ on väga suur, $<$ isik $>$ on täiesti anonüümne, $<$ Priit $>$ on täis terve) või sündmust tervikuna (<aruandlus $>$ on ju korraline, <lollus $>$ on ju totaalne, <arutelu $>$ on nii loid). Lahtiseks jääb, kas omaduse määr on seotud elusa referendi ning rõhutamine abstraktse elutu referendiga.

\subsubsection{Verb-verb-adverb ehk VVD}

VVD on eitava kõne muster: eituspartikkel $e i+$ verb IND:IMPERF, harvem IND:PRES (vastavalt 46 ja 36 näidet) + adverb (ei tulnud kaua <oodata>, ei olnud enam <endine>, ei tahtnud siia <kedagi teist>, ei rahuldanud siiski, ei mõelnud pikemalt, ei kuulanud tookord ja ei kao kuhugi, ei juhtu üldse, ei ole ju <säilinud>, ei ole mitte <varas>, ei vaata tagasi, ei saa vastu). Seega on eitava kõne VVD-struktuuri kasutus morfosüntaktiliselt piiratum kui VDA (vt punkt 1.2.1).

Analüüs tõi esile verbi ja adverbi semantika, verbi ajavormi ning analüütiliste verbide esinemuse vahelise seose.

1) Üle poole eitava kõne lihtmineviku (NEG:IMPERF) näidetest sisaldavad sünteetilise verbi finiitvormi. Verbivalik on leksikaalsemantiliselt piiratud (vt ka punkt 1.1.1): a) modaalverbid ei tahtnud, ei saanud, ei pidanud, ei lubanud; b) eksistentsiaalverb ei olnud; c) mõttetegevust tähistavad verbid ei mõelnud, ei kavatsenud, ei teadnud, seisundiverb ei norutanud; d) liikumis- (ei läinud, ei tulnud) ja tajuverbid (ei näinud). Esile tuli kuus ühendverbi (ei tulnud välja, ei pidanud vastu, ei teinud väljagi, ei andnud järele, ei saanud valla 'lahti', ei kippunudki tagasi), ent analüütiliste verbide tegelik tekstikasutus eitava kõne VVD-struktuuri paremkontekstis on tunduvalt suurem, sest eesti keele sõnajärjele iseloomulikult lahutab analüütilise verbi komponente vähemalt üks adverb (ei saanud(ki) enam <kokku>, ei näinud 
päratu < välja>, ei ületanud iialgi < piire>, ei pannud nagu <tähelegi>, ei saanud isegi <aru>), sagedamini aga mitu adverbi (ei vaadanud mitte sulle otsa, vaid ..; ei vihtunud seal midagi tantsu, vaid istus vaikselt nurgas ja .. ).

Seega leidub VVD-struktuuri paremkontekstis nii ühend- kui ka väljendverbe, mille põhjaks on tuumverbid saama, andma, tegema, tulema, pidama. Sama tendents tuleb esile ka eitava kõne olevikuga: näidete hulgas oli viis analüütilist verbi (ei lenda ära, ei saa vastu, ei vaata tagasi ja ei ole võlgu, ei seisa paigal), kuid nende tegelik arv suureneb kohe, kui laiendada verbi paremkonteksti: ühendverbid $e i$ kao kuhugi <ära>, ei roni enam <üles>, ei pea kaua <vastu>, ei pakigi seekord $<$ sisse $>$, ei vaata kunagi $<$ tagasi $>$ ja väljendverbid ei võta $k u i-$ dagi <vedu>, ei vaata kunagi <silma>, ei saa päriselt <aru/pihta $>$. Järelikult on verbi paremkontekst analüütiliste verbide kasutusala. Seda näitavad nii eitava kõne VVD ja VDD (vt punkt 1.1.3) kui ka jaatava kõne VDD kasutusmustrid (vt punkt 1.1.1).

2) Eitava kõne oleviku vormis korduvad ei ole, ei saa, ei pea, ei kao, ei vaata. Leidub ka näiteid erinevatesse semantilistesse rühmadesse kuuluvate ainukordsete verbidega (ei roni enam, ei keera üldse, ei juhtu üldse, ei toimu praegu, ei tee veel), kuid sellele vaatamata on eitava kõne oleviku finiitvormi kasutus leksikaalsemantiliselt rohkem piiratud kui eitava kõne lihtminevikku sisaldavates näidetes. Stereotüüpsena eristub nende seast sageli korratud väljend ei ole(gi) enam.

3) Ilmselt struktuurianaloogia tõttu laieneb adverbi enam (ei ole(gi) enam) kasutusala ka täistähenduslikele verbidele (ei klappinud enam, ei näinud enam, ei tahtnud enam, ei saanud enam ja ei saa enam, ei roni enam). Sel juhul on verb lihtmineviku ja oleviku vormis kinnistunud rõhupartiklitega $j u, k a$, üldse, sugugi, mitte, isegi; sama kehtib aja- ja kohamääruste veel, tookord, seekord, praegu ning seal, siin, sinna kohta. 


\subsection{Struktuuri komponentide avar/piiratud morfosüntaktiline varieerumine - leksikaalsemantiliselt ja funktsionaalselt kinnistunud/piiratud kasutusega adverbid}

Struktuuri komponentide avarat morfosüntaktilist varieerumist saadab leksikaalsemantiliselt ja funktsionaalselt kinnistunud adverbivalik (VDS), piiratud morfosüntaktilise varieerumisega kaasneb adverbi leksikaalsemantiline ja funktsionaalne piiratus (VSD, VPD).

\subsubsection{Verb-adverb-substantiiv ehk VDS}

VDS-struktuuri näiteid ei ole kuigi palju (kokku 44, jaatavas kõnes 39 ja eitavas 5), samas valitsevad komponentide vahel keerulised leksikaalsemantilised ja funktsionaalsed seosed, mille alusel kujunevad idiomaatilised väljendverbid. Sõnajärje varieerimine võimaldab lisada ekspressiivseid ja pragmaatilisi tähendusvarjundeid ning subjektiivseid hinnanguid, mistõttu on VDS-struktuuri kasutatud möönduse, hoiatuse, info aktualiseerimise eesmärgil.

1) Morfosüntaktiliselt varieerub kõneliik, jaatavas kõnes ka verbi IMPERF ja PRES:SG:3. SUB:NOM on enamasti subjekti (tuleb ikka igavus <peale>, hakkab ka velsker <naerma>), harvem predikatiivi funktsioonis (oli seal koolidirektor, on alles algus); SUB:PART on partsiaalobjekt (tõi endiselt lisa, sai täiesti aru), eituse korral subjekt (pole ka pimedust, pole niipea tulekut).

2) Verbi leksikaalne varieerumine on kitsas: a) olema finiitöeldise ja abiverbina; b) finiitverbid tooma, saama, tulema, hakkama, tõmbama, äratama ja uurima + sUB:PART moodustavad väljendverbe (sai täiesti aru, tõmbas sügavalt/sügavasti hinge, äratas teinekord imestust) ja tugiverbiühendeid (tõi endiselt lisa). Idiomaatilisi ja kollokatiivseid üksusi esineb ka olema-verbiga, eriti jaatava ning eitava kõne olevikuvormiga (on juba liig, on juba hammas <verel>, on vaid illusioon (mõttekuju); pole enam pääsu, pole niipea tule$k u t$, <ei> ole kah lugu). VDS-struktuuri jaatava kõne näidete alusel 
moodustub skaala väljendverbidest (sh tugiverbiühendid) vabade verbi-substantiivi ühenditeni: a) analüütiline verb, millel on samatähenduslik sünteetiline verb (tõmbas hinge puhkas, sai aru mõistis, tõi lisa lisas), harva teine analüütiline verb (äratas imestust pani imestama); b) verbi-substantiivi idiomaatilised ja kollokatiivsed ühendid, millel samatähenduslik paralleelvariant puudub (on juba liig, on vaid illusioon/mõttekuju; pole enam pääsu, pole niipea tulekut, $<\mathrm{ei}>$ ole kah lugu; oli päris ime, oli rohkem 'pigem' hingearst, oli juba mälestus jm); c) üksikud verbi-substantiivi ühendid (oli seal keskkoolidirektor, on juba maja <ja auto $>$ ). Kahel esimesel juhul on adverbil samaaegselt mitu funktsiooni, kolmandas (vabad sõnaühendid) vaid määruse funktsioon (tähistab kohta ja aega).

3) Kinnistunud idiomaatilises VDS-struktuuris, nagu oli alles uni, oli päris ime, tõmbas sügavalt/sügavasti hinge, $<\mathrm{ei}>$ ole kah lugu, pole enam pääsu, on juba hammas <verel>, tuleb ikka igavus <peale >, on substantiivi sünonüümne asendamine võimalik, kuid semantiliselt piiratud. Olenemata sõnajärjest ja adverbi valikust, nt tuleb ikka igavus <peale $>$ (VDS) igavus tuleb muidugi $<$ peale $>$ (SVD) igavus $k a$ tuleb <peale> (SDV), saab substantiivi asendada vaid hingelisi seisundeid ja tundeid kirjeldavate sõnadega (nt tuleb ikka igavus/ uni/naer/nutt/tusk peale, vrdl *tuleb ikka maja/maantee/ratas peale). Sõnajärje ja adverbide varieerimine võimaldab kõnelejal vastavalt suhtlusvajadusele väljendada erinevaid emotsionaalseid, ekspressiivseid, modaalseid ning pragmaatilisi tähendusi.

4) VDS-struktuuris kasutatakse korduvalt avaratähenduslikke rõhumäärsõnu juba, alles, küll, vaid, $k a(h)$, mida saab üksteisega asendada. Seega peaks neil olema ka avarad distributiivsed omadused, kuid VDS on kinnistunud kasutustega muster. Vastuolu seletus tuleneb tekstist, kus väike rühm adverbe esineb erinevates semantilis-pragmaatilistes funktsioonides, nt et väljendada negatiivset või positiivset hinnangut, lisada modaalseid ja ekspressiivseid varjundeid: oli päris ime 'tõepoolest ime, tõesti ime', oli alles ime 'üllatus, emotsionaalne hinnang, oli juba ime 'ootamatu, ebareaalne' oli ka 
ime 'kõige muuga võrreldes'; on juba liig < mis liig> 'ületab kõik piirid'; on juba hammas <verel> 'on maitse suhu saanud', 'ei saa enam pidama'; oli alles uni 'sügav, raske uni' või 'tore unenägu'; on alles algus 'suurem osa seisab ees', 'negatiivne või positiivne hinnang'; on alles töö 'tüütu, raske, mõttetu töö' või 'vahva töö.'

5) Adverb koos järgneva substantiiviga aktualiseerib objekte, sündmusi ja olukordi; võimaldab hoiatada potentsiaalset adressaati (mittesoovitud) tagajärgede eest; väljendab mööndust; tähistab tegevuse kulgemist ajas, kirjeldab tegevuslaadi. Adverbi funktsioonid VDSstruktuuris on:

a) väite tõesuse kinnitamine ja rõhutamine sündmuse iseloomustamiseks (on tõesti mure, on küll tunne, on siiski õigus, on muidugi pühapäev); negatiivse hinnangu (on vaid mõttekuju, on ka illusioon, on juba proosa), eitavas kõnes ka negatiivse ekspressiivse/ modaalse värvingu lisamine (pole enam pääsu 'väljapääsmatus, võimatus', pole niipea tulekut 'võimatus');

b) hoiatamine (mittesoovitud) tagajärgede või eelseisva(te) sündmus(t)e eest (on alles algus, on juba proosa). Adverb rõhutab substantiivi semantikat, viidates samas järgnevatele sündmustele, mis võivad mõjuda kas negatiivselt või positiivselt;

c) möönduse väljendamine, kui eitava kõne olevikuvormile järgnevad rõhupartiklid ju, ka, kah (pole ju ema teha, <ei> ole kah lugu olnud);

d) tegevuslaadi leksikaalne täpsustamine väljendverbi (sh tugiverbiühendi) komponentide vahel, nt tõi endiselt 'tavapäraselt' lisa - pidev tavapärane tegevus; sai täiesti aru - sündmuse ammendatus, seisundimuutus ja selle rõhutamine; äratas teinekord 'mõnikord', 'vahetevahel' imestust - aeg-ajalt korduv seisund; uuris enne olukorda - ühe tegevuse ajaline eelnemine teisele; tõmbas sügavalt/sügavasti hinge - tegevuse intensiivsus. Adverbide sünonüümne või antonüümne asendamine on küll võimalik, kuid muudab rõhuasetusi ja võimaldab täpsustada subjektiivmodaalset hinnangut, nt tõi endiselt/ikka/muidugi/ 
kindlasti/arvatavasti .. lisa; sai täiesti/pooleldi/ilmselt/arvatavasti/kindlasti .. aru;

e) tegevuse või osalis(t)e aktualiseerimine, et iseloomustada sündmust tervikuna (on ikka tõsi, on tõesti mure) või seisundit (on küll tunne <, et>, on siiski õigus, on isegi rahakopikas < taskus/ varuks/olemas $>$ ), markeerida subjekti (on ikka velsker, on muidugi pühapäev). Kui subjekt on konkreetne isik (nt velsker), siis on fookus isikul. Üldnime saab asendada isikunime ning isikut või ametit märkiva substantiiviga (on muidugi velsker, on küll Andres, on tõesti ôppejõud, on ikka apteeker).

6) VDS-struktuuri komponentide sõnajärg varieerub: neutraalsest predikaat-subjekt sõnajärjest saab ekspressiivne, lisandub kõnekeelsus (on ikka tõsi ja tõsi ikka on <, et>), muutuvad rõhuasetused (hakkab ka velsker $<$ naerma $>$ ja velsker ka hakkab $<$ naerma $>$ ) ja komponentide süntaktilised funktsioonid (on tõesti mure $<$, et $>$ ja mure on tõesti <suur >; on küll tunne <, et $>$ ja tunne on küll < selline, et $>$; tuleb ikka igavus $<$ peale $>$ ja igavus tuleb ikka $<$ peale $>$; on juba maja $<$ valmis $>$ ja maja on juba <valmis $>$; on juba hammas < verel $>$ ja hammas on juba <verel>). Sõnajärje varieerimine näitab veel kord, kuivõrd multifunktsionaalne on adverbide tekstikasutus. Kahtlemata teeb kõik eespool kirjeldatu VDS-struktuuri tekstikasutuse keeruliseks.

\subsubsection{Verb-substantiiv-adverb ehk VSD}

VSD-struktuur on oluline analüütiliste ühendverbide kasutamisel (66 näidet). Komponentide sõnajärje muutmine lisab ekspressiivseid ja pragmaatilisi tähendusvarjundeid, hinnanguid, kuid need pole seotud samade nähtustega, millest oli juttu eelmises VDS-punktis (vt 1.3.1).

1) Esiteks on VSD-struktuuril morfosüntaktiline dominant - verb kindla kõneviisi lihtmineviku ainsuse 3. pöördes (IND:IMPERF:SG:3): pööras pilgu ära, vastas Kuivik lihtsalt, küsis Tehvan pahaselt, jäi tõkkepuu alla, oli kirjapandu alles, pööras mansetid ülespoole, läks lukk rikki, oli ümbrusest lahti, vaatas kass uuesti. Dominandi olemasolu 
annab märku võimalikust stereotüüpsusest, ent struktuurile lisavad keerukust substantiivi ja adverbi varieerumine, samuti referentsiaalsed seosed: a) adverbi funktsionaalne potentsiaal ulatub verbipartiklist (pööras pilgu ära) määruseni (vastas Lutrin ebamääraselt); b) substantiivi funktsioonid sõltuvad referentsiaalsest seosest - elusat referenti tähistab isikunimi (küsis Tehvan pahaselt), harva isikut märkiv üldnimi (ütles neiu tasa, sirutas mees jälle <käe välja>) ning neil on subjekti funktsioon; elutuid referente tähistatakse üldnimedega ja neil on nii subjekti (muutus samm veelgi <aeglasemaks $>$ ) kui ka totaalobjekti (sai alguse juba <eile>), harva käändelise määruse funktsioon (asus rajoonikeskusest niipalju <eemal, et ..>).

2) Mida stereotüüpsem on verbi semantika (valdavalt kõne- ja tuumverbid) ning morfosüntaks (IMPERF:SG:3 finiitöeldisena), seda huvitavamaid seaduspärasusi ilmneb elusat/elutut referenti tähistava substantiivi morfosüntaksis (sG:NOM, GEN ja ELA vastavalt subjekti, objekti ja käändelise määrusena) ning adverbi tekstifunktsioonides. Selgelt tulevad esile seosed kõneverbide (lausus, vastas, ütles, küsis, õiendas), elusa referendi (tavaliselt isikunimi - Hardi, Tali, Tehvan, harvem üldnimi kass, ajakirjanik, jõmm), järgneva adverbi valiku ja funktsioonide vahel (tavaliselt $l t$-lõpuline viisimäärus, nt lausus Relli ópetlikult, ka ebamääraselt, lihtsalt, skeptiliselt, tähtsalt, agressiivselt, pahaselt). Tuumverbide läks, jäi, võttis, pani, ajas semantiline avarus loob eelduse analüütiliste verbide moodustumiseks koos subjekti (läkski mäng lahti, läks lukk rikki, jäi tõkkepuu alla, jäi hing kinni) ja totaalobjekti tähistava substantiiviga (võttis kaane ära, võttiski tulijad vastu, pani noa kõrvale, ajas silmad uuesti <punni>). Konteksti arvestades on analüütiliste verbide esinemus veelgi suurem, sest verbipartikkel, kivinenud noomeni vorm või infinitiiv paremkontekstis on põhiverbist eraldatud tavaliselt mitme adverbiaalse komponendiga (subjekti sisaldavates näidetes oli vastus $k a<$ käes $>$, sirutas mees jälle <käe välja>, vaatas kass uuesti <tagasi $>$; objekti sisaldavates näidetes surus käsivarred kõvasti $<$ kokku>, pesi kleidi just 'äsja' <puhtaks >). 
3) Adverbi funktsionaalne potentsiaal sõltub verbi sünteetilisusest/ analüütilisusest ja semantikast. Kuna analüütilised verbid on valdavalt ühendverbid, siis on ka adverb tavaliselt grammatiseerunud verbipartikkel (imes valguse ära, võttis buketi vastu, pani noa kõrvale, segas kokteilid valmis, torkas kõrred sisse), SUB:SG:GEN või sG:NOM aga totaalobjekt. Sünteetiliste verbide puhul on adverb tavaliselt sisutühi rõhupartikkel $k a$ või erinevat päritolu ja liiki määrus, SUB:SG:NOM tähistab elusat/elutut referenti subjekti funktsioonis (kadus ülempreester kuhugi, vastas Lutrin ebamääraselt, ütles neiu tasa), v.a käändelise määruse juhtumid suB:SG:ELA vormis (irdus puuihust aeglaselt).

Niisiis esinevad verbi, substantiivi ja adverbi kasutuses kindlat liiki semantilis-süntaktilised kombinatsioonid, mida üksikasjaliku lingvistilise analüüsita pole kuigi lihtne märgata, kuid mis on tekstiloome seisukohalt olulised.

\subsubsection{Verb-pronoomen-adverb ehk VPD}

VPD-struktuur algab kindla kõneviisi lihtmineviku ainsuse 3. pöörde vormiga (IND:IMPERF:SG:3, 55 näidet), järgneb personaalpronoomeni lühivorm $t a$, mida kasutatakse valdavalt subjekti funktsioonis, harva ka partsiaalobjektina (5 näidet). Finiitverbi regulaarne kooskasutus pronoomeniga ja komponentide suhteliselt kitsas leksikaalsemantiline varieerumine toetavad stereotüübi kujunemist (oli ta siin, oli ta veel, küsis ta siis, lausus ta siis, leidis ta nü̈̈d, tüdines ta peagi, arvas ta ometi).

1) Üle poole näidetest (34 näidet 55-st) katavad kahe leksikaalsemantilise rühma verbid: a) kõneverbid IMPERF:SG:3 finiitöeldisena ( $k u ̈ s i s$ ta siis, päris ta siis, vastas ta tõsiselt, lausus ta mõtlikult, kuulutas ta häälekalt) ja b) olema IMPERF:SG:3 abiverbi funktsioonis (oli ta salaja $<$ mõelnud $>$, oli kõik taas <korras $>$ ). Ainukordseid või paar korda esinenud verbe leidus vähe (võttis ta rahulikult, võttis ta välja, sai ta vaid, sai ta korraga, tüdines ta peagi, istus ta siin, lõi ta koketselt). 
2) Pronoomeni varieerumine on piiratud: subjektina domineerib personaalpronoomeni lühivorm $\mathrm{ta}$ (40 näidet 55 -st), harva demonstratiivpronoomen see (too) või determinatiivpronoomen kõik (vastavalt näis see lausa, jäi too uuesti ja oli kõik taas, põles kõik sisse), partsiaalobjekti funktsioonis ka refleksiivpronoomen end, ennast (tabas end uuesti, väänas end lahti, nimetas ennast $k a$ ).

3) Koos kõneverbidega kasutatakse sagedamini lt-lõpulisi adverbe viisimääruse funktsioonis (vastas ta tõsiselt, kuulutas ta häälekalt, küsis ta variserlikult, lausus ta mõtlikult/karmilt), rõhumäärsõnade valik on piiratud (korduvad ka, küll, nü̈̈d, veel, vaid), kohamäärusena esinevad üksikud proadverbid (siin, siit, seal), verbipartiklite ja seega ühendverbide esinemus on marginaalne (võttis ta välja, põles kõik sisse, väänas end lahti).

Niisiis kujutab VPD endast stereotüüpsusele pretendeerivat mustrit, mille komponendid on leksikaalsemantiliselt, morfosüntaktiliselt ja funktsionaalselt piiratud, nt olema abiverbina liitöeldises + ta-subjekt + ADV määruse funktsioonis, harva verbipartiklina (oli ta siin <varemgi käinud / rebast näinud / Emmaga kohtunud ..>; oli ta salaja <mõelnud, et .. / arvanud, et .. / lahkunud $>$; oli ta tagasi <tulnud/vaadanud/pöördunud/andnud/saanud ..>).

\section{Adverbita mustrid}

Adverbita struktuure on tekstikasutuses arvuliselt sama palju kui adverbi sisaldavaid, ent nende osakaal jääb viimastele tunduvalt alla, v.a VAS. Tekstikasutuses ilmneb erinevaid verbi-substantiivi kombinatsioone, mille põhjal ühe grupi moodustavad VAS, VPS ja VVS ning teise VSK, VAJ ja VSS. 


\subsection{Struktuuri komponentide avar morfosüntaktiline varieerumine ja leksikaalsemantiline sidusus}

\subsubsection{Verb-adjektiiv-substantiiv ehk VAS}

Tekstikasutuses on adverbita VAS-struktuur (53 näidet) niisama oluline kui adverbi sisaldav VPD-struktuur (vt punkt 1.3.3). Morfosüntaktiline varieerumine on avar: a) verb IND:IMPERF ja PRES:SG:3 (vastavalt 24 ja 23 näidet), harva IND:IMPERF:PL:3 (6 näidet), nt tekkis ähmane lootuskiir, oli vaimukas tekst; süttisid üksikud tuled; on suur tüdruk, kostab päästev telefonihelin; b) verbi ainsuse-mitmuse valik sõltub subjekti, harva predikatiivi funktsioonis kasutatud nominatiivsest substantiivist (44vs. 9 näidet); c) adjektiiv eestäiendina ühildub substantiiviga arvus ja käändes. Samas ei tulene VAS-struktuuri keerukus mitte niivõrd verbi, adjektiivi või substantiivi morfosüntaksist, kuivõrd nende semantilisest sidususest (kollokatiivsusest), verbide leksikaalsemantilistest piirangutest ja sõnajärjest tingitud süntaktilistest funktsioonidest.

1) VAS-struktuuri keerukuse olulisim aspekt on kollokatiivsus (ähmane lootuskiir, tavatu küsimus, täielik vaikus, seletamatu erutus, professionaalne vilumus, terane tüdruk, särav hõbekett, päästev telefonihelin) ja idiomaatilisus (osavad käed, hea toon, jumalik hääl, võorras veri, must auk, terav keel). Autorikujundeid (tolmune igivaikus, haraline taimevidu, kumasid väikesed viljad) ning vabu sõnaühendeid (kahvaturoosa kolmnurk, vabamü̈̈rlik asjandus, pikk reisikasukas, viimane arvestus) esineb harva. Sünonüümsed asendused teevad kollokatsioonist enamasti vaba sõnaühendi (ähmane/väike lootuskiir ning tavatu/harjumatu/eriskummaline/imelik/naljakas küsimus).

2) Öeldise tüübi seos sõnajärje ja verbi leksikaalsemantiliste piirangutega ilmneb kahes aspektis.

a) Finiitöeldisena kasutatakse täistähenduslikke verbe PREs:SG:3 (lebab, kostab, areneb, tuleb, püsib), IMPERF:SG:3 (tekkis, kasvas, seisis, jäi, peitus, ärkas, kõlas, paisus, nõudis, leidis, <millest> sai 'tekkis', teatas, haaras, lõi, kumas) ja IMPERF:PL:3 (kumasid, süttisid). Sagedamad on tajuverbid kumama, kõlama, kostma, paistma. 
b) olema IMPERF ja PRES:SG:3 (harva IMPERF:PL:3) on kas abiverb (liitajad, liitöeldis) või täistähenduslik eksistentsiaalverb. Funktsioonide eristamisel tuleb arvestada kontekstiga nii verbist vasakul kui ka paremal. Näiteks olema PREs:SG:3 esineb võrdselt nii finiitöeldise kui ka koopulana. Esimesel juhul järgnevad finiitvormile paremkontekstis adjektiivne eestäiend ja subjekt ( $<$ kaelas $>$ on särav hõbekett $\sim$ särav hõbekett on $<$ kaelas $>$; <mägedes $>$ on hõre ôhk; <nurgas> on vana viiul). Vasakkontekstis võib verbile eelneda erinevaid laiendeid, nt määrus (<esimesel korrusel > oli väike köök, <ruumis > oli täielik vaikus, <kehas> oli kummaline nõrkus), sihitismäärus (<meie emadel $>$ olid osavad käed), subjektiivmodaalset hinnangut väljendav üldlaiend $(<$ minu meelest $>$ oli vaimukas tekst $)$. Teisel juhul järgneb koopulale SUB:SG:NOM predikatiivi funktsioonis ja subjekt paikneb vahetult verbi ees ( $<$ see $>$ on absurdne teooria, $<\mathrm{karu}>$ on imeline loom, $<$ see $>$ ongi oige hoolitsus, on ühtne protsess, $<\mathrm{ta}>$ on suurl terane tüdruk, on võõras veri). Liitöeldise komponente lahutav adjektiivne eestäiend ühildub põhisõnaga käändes ja arvus.

Niisiis on VAS-struktuuri kasutus leksikaalsemantiliselt ja morfosüntaktiliselt keeruline, sobib pigem kirjeldava esituslaadiga (eksistentsi, looduse, inimsuhete teema, subjekti omadused jm). Keerukus seisneb adjektiivi-substantiiviühendite kollokatiivsuses ja idiomaatilisuses, mis sõnajärje muutudes võib kaduda.

\subsubsection{Verb-pronoomen-substantiiv ehk VPS}

VPS-struktuur esineb harva (16 näidet), kuid selle kasutus on sama keeruline nagu eespool kirjeldatud VAS-struktuuril (vt punkt 2.1.1). Komponendid varieeruvad morfosüntaktiliselt ja neil on erinevaid funktsioone, mis tulevad esile kolme selge mustrina.

1) Verb IND:PREs:SG:3 + demonstratiivpronoomen see/too SG:NOM eestäiendina ja suB:SG:NOM subjekti funktsioonis (tuleb see nüanss <selgelt esile>, hakkab see inimene <rääkima>, pöördub see rüngas 
$<$ tema enda vastu>, lipendab sama paber <kausta vahelt välja $>$, $<$ rakendis $>$ on see loom <taltsas $>$, on too paratamatus $<$ tõepoolest olemas $>$ ). Tegu on eesti keele tüüpilise sõnajärje näitega, kus liitajavormi, liitöeldise ja lihtöeldisena kasutatud analüütilise verbi komponente lahutab subjekt koos eestäiendiga (nt <siis> hakkab see inimene $<$ rääkima $>$ ).

2) Verb IND:IMPERF:SG:3 + demonstratiivpronoomen see/too SG:NOM eestäiendina või sUB:SG:ELA ajamääruse funktsioonis (toimus sel aastal, muutus sel ajal, oli sel/tol päeval, oli sel suvel). See on ajamääruslik leksikaalgrammatiline stereotüüp verbist paremal, mis seob sündmuste kirjeldamisel erinevaid ajaplaane.

3) Verb IND:IMPERF:SG:3 + personaalpronoomeni lühivorm ta subjekti funktsioonis või suB:SG:GEN totaalobjektina, nt tegi ta järelduse, tegi ta ettepaneku, tegi ta otsuse, lõi ta pilgu <maha>, leidis ta trahvikviitungi. Enamasti on tegu idiomaatiliste väljendverbidega nagu tegi järelduse/ettepaneku/otsuse, lõi pilgu maha.

Niisiis on VPS-struktuuri kolme mustri aluseks verbi, pronoomeni ja substantiivi grammatika. Struktuuri komponentide vahele saab lisada erinevat liiki adverbiaalseid laiendeid ja eestäiendeid, mis teeb selle kasutuse veelgi keerulisemaks, nt $<$ nüüd $>$ tegi ta $<$ kiire/kärmelt $>$ järelduse, $<$ et ..> - ajamäärus nü̈̈d, eestäiendina kasutatud adjektiiv kiire või adverb kärmelt viisimäärusena, põhiverbi objektikäändeline laiend järelduse.

\subsection{Struktuuri komponentide piiratud morfosüntaktiline,} leksikaalsemantiline ja referentsiaalne varieerumine

\subsubsection{Verb-substantiiv-adpositsioon ehk VSK}

Leksikaalsemantiliselt piiratud ja morfosüntaktiliselt vähe varieeruvat VSK-struktuuri kasutatakse harva (22 näidet), samas on tegu selgepiirilise mustriga, milles verb IND:IMPERF(PRES):SG:3 on tavaliselt finiitöeldise funktsioonis, sUB:SG:GEN aga reeglipäraselt adpositsiooni laiend. VSK-struktuuri morfosüntaktilised piirangud käivad käsikäes leksikaalsemantiliste ja kontekstuaalsetega. 
1) Finiitöeldisena kasutatakse peamiselt liikumisverbe (läks, tuli/tuleb, astus/astub, käis, liikus, ronis, kummardus), mõnikord ka seisundi(seisis, istus), faasi- (hakkab) ja tuumverbe (jäi).

2) Sageli kasutatud adpositsioonid on poole (liikus ukse poole, läks kodu poole; astub kunstihoone poole, tuleb kaitsetu poole); juures - juurde (istus karja juures, käis poe juures; astus tüdruku juurde, läks kapi juurde); alt - all (tuli okastraadi alt, kobas riiuli alt; on kardinamustri all); kõrval - kõrvale (seisis puuvirna kõrval; jäi restorani kõrvale) ning peal - peale (oli pooli peal; mustas raua peale).

3) Verbide vasakkontekstis paikneb elusat referenti tähistav subjekt $(<$ varas, Rein, ta $>$ ronis kassi kombel <trepist üles $>)$, adpositsioon markeerib subjekti liikumissuunda (<ema> kummardus töö/sahtli kohale, <varas> liikus ukse poole, <Mart> läks kapi juurde, <mees> astus tüdruku juurde, <naaber $>$ seisis puuvirna kõrval, <siil > tuli okastraadi alt). Erandiks on olema ja veel paar verbi, mis semantiliselt ei ole mõeldavad elusa referendi tegevusena ja seostuvad pigem esemete, asjade paiknemisega ruumis või nähtustega ajas (<lõng $>$ oli pooli peal, <joonis $>$ on kardinamustri all, <uus tsükkel $>$ hakkab täiskuu ajal, <auto> jäi restorani kõrvale).

\subsubsection{Verb-adjektiiv-konjunktsioon ehk VAJ}

VAJ-struktuur on koordinatiivse seose stereotüüp, mida kasutatakse loendamisel (9 näidet): olema IND:IMPERF:SG:3 koopula funktsioonis + ADJ:SG:NOM (predikatiiv) + koordinatiivne sidesõna ja. Paremkontekstis lisandub veel üks adjektiiv. Kirjeldatakse vähemalt kahe elusa/elutu referendi (inimesed, esemed-asjad), seisundite, olukordade jm tunnuseid (<maa > oli tühi ja <paljas >, <noorperemees $>$ oli uhke ja <edev>, $<$ nuga $>$ oli terav ja $<$ sile $>$, <tal $>$ oli ainuline ja $<$ särav anne $>$, $<$ toas $>$ oli umbne ja $<$ pime $>$, <ta pilk $>$ oli külm ja $<$ ükskõikne $>$ ). Loendatavad tunnused peavad sobima objektiga semantiliselt ja referentsiaalselt. Tegu on kollokatiivsete üksustega: pilk võib olla külm (kale) ja ükskõikne, mitte kõle või kalk; süda võib olla külm ja kalk, ilm seevastu tuuline ja kõle 
jne. Niisiis võivad morfosüntaktiliselt piiratud, esmapilgul lihtsad, harva esinevad ja standardselt kasutatud mustrid sisaldada leksikaalsemantilisi ja referentsiaalseid kitsendusi, mis teeb mõnikord nende tekstikasutuse keeruliseks.

\subsubsection{Verb-substantiiv-substantiiv ehk vSS}

Morfosüntaktiliselt piiratud VSS-struktuur esineb harva (5 näidet): olema IND:PRES:SG:3 koopula funktsioonis, järgnevad sUB:SG:GEN eestäiendina ja sUB:SG:NOM predikatiivi funktsioonis $(<\mathrm{tal}>$ on asjatundja pilk, $<$ neil $>$ on hamba parandus $<$ pooleli $>$, $<$ kas see siis $>$ on inimese tegu). Analoogselt VAS-struktuuriga (vt punkt 2.1.1) tingib ka VSS üsna üheselt, kuidas ja milliseid lekseeme-vorme verbi vasakkontekstis omavahel kombineerida. Emakeelekõnelejal on seda lihtne ära aimata.

\subsubsection{Verb-verb-substantiiv ehk VVS}

VVS-struktuuri esinemus (5 näidet) on sama marginaalne kui VSS (vt punkt 2.2.3). Muster algab IND:NEG:IMPERF vormiga, järgneb SUB:SG:PART partsiaalobjekti funktsioonis, nt ei asetanud oskust <teadmistest kõrgemale>, ei öelnud sõnagi (kasutatav vaid eitavas kõnes, leksikaalsemantiliselt kinnistunud), $<\mathrm{nad}>$ ei saanud sõnagi $<\mathrm{aru}>$ (väljendverb), $<\mathrm{me}>e i$ saanud aru (väljendverb), <maja $>$ ei pidanud sooja (väljendverb). Tegu on morfosüntaktiliselt kinnistunud idiomaatiliste üksustega, tavaliselt väljendverbidega või väljenditega (ei asetanud oskust teadmistest kõrgemale).

\section{Arutelu}

Uurimuse eesmärk oli leida, lingvistiliselt seletada ja kirjeldada eesti ilukirjanduskeele kasutusmustreid verbi paremkontekstis, tuua esile morfosüntaktilised, leksikaalsemantilised ja funktsionaalsed seosed mustrite avara/piiratud varieerumise, kinnistumise ja stereotüüpide tekkimise vahel. Vaatluse all oli kolm küsimust. 


\section{Millised mustrid verbist paremal on keeleomased, kas samuti adverbi sisaldavad, nagu verbi vasakkontekstis?}

Verbi paremkontekstist leitud mustrite hulgas on adverbi sisaldavaid struktuure arvuliselt sama palju kui adverbita (kuus ja kuus), ent kummagi rühma mustrite katvus on oluliselt erinev: adverbi sisaldavad struktuurid haaravad $81 \%$ ja adverbita $19 \%$ kasutustest. Vaid üks adverbita muster - VAS (9\%) - on osakaalult võrreldav adverbi sisaldava VPD-ga (9\%). Seega näitavad siinsed verbi paremkonteksti analüüsi tulemused, nagu analoogne verbi vasakkonteksti uurimuski (vt Eslon 2014b), et mõlemas positsioonis kasutatakse valdavalt adverbi sisaldavaid mustreid, et adverb on tekstikasutuses levinum sõnaliik, mille funktsioonid ulatuvad partiklist ja (teksti) sidususvahendist kuni subjektiivmodaalse hinnangusõna ja määrusliku laiendini.

Adverbi avar funktsionaalne potentsiaal on tingitud ühelt poolt sõnaliigi süsteemsest staatusest: adverb on vastanduse verb/noomen neutraliseeriv liige. Teisalt on adverbi sisaldavatel struktuuridel kindel roll eesti keele n-ö vaba sõnajärje korrastamisel, sest mida vabamana keele toimimist käsitleda, seda kitsamad on tegelikud kasutusreeglid, seda piiratum morfosüntaktiliste mustrite hulk ning seosed struktuuri komponentide vahel. Nii esimesel kui ka teisel teguril on oma osa adverbi tekstifunktsioonide kujunemises: süsteemne staatus tagab sõnaliigi kasutuspotentsiaali, sõnajärjemallid on seotud piirangutega komponentide kombineerimisel. Kuigi sõnaliigijärjendite andmekaeve ei tugine siinses uurimuses osalausele nagu sõnajärjepuudes (vt Matsak jt 2010), haakuvad saadud tulemused omavahel, lisades uue vaate eesti keele sõnajärje diskursuskesksele käsitlusele, lause põhi- ja baassõnajärje küsimusele (Remmel 1963; Ehala 2001), seostele lause infostruktuuri (Tael 1988; Lindström 2005) ning süntaksiga - subjekti, objekti ja predikaadi sõnajärg, adverbiaali paiknemine seotud laiendi ja üldlaiendina, kõrvallause sõnajärg jm (nt EKG II; Sahkai 1999; Metslang \& Matsak 2010; Ogren 2015). Sõnajärjemallide loomulikkuse hindamine emakeelekõneleja ja eesti keele õppija 
seisukohalt kinnitas veel kord, et emakeelse inimese jaoks on V2-reegel "psühholingvistiliselt reaalne ning kõige häirivam on laiendi paiknemine lausealgulise subjekti ja verbi vahel” (Kaivapalu 2010: 103). Ka subjektiga algavas sõnajärjepuus järgneb süntaksimärgendile @SUBJ (subjekt) tavaliselt @FMV (verbi finiitvorm) ja üks kuni neli @ADVL (adverbiaal),nt Perenaine @SUBJ istub @FMV köögis @ADVL söögilaua ääres @ADVL taburetil @ADVL, (vt Matsak jt 2010: 81). Sama näitab ka verbi finiitvormiga algav sõnajärjepuu, kus verbist paremal asuvale adverbiaalile järgneb "suure tõenäosusega teine ja kolmaski adverbiaal", nt Jäin @FMV seejärel @ADVL kohe@ADVL magama. Kui sõnajärjepuus on verbi finiitvormi järel objekt või subjekt, siis lisandub adverbiaal kolmanda komponendina, ntPane @FMV silmad @OBJ kinni @ADVL. (Matsak jt 2010: 73-74) Katse leida bigrammid vale sõnajärjega lausest ${ }^{*}$ Kaitsevägi hakkab vaid 24-tunnise etteteatamisega õppustele kutsuma (Delfi 16.11.2016) tõi vigase järjendi üheselt esile. Subjektiga algava lause bigrammidest *etteteatamisega õppustele; Kaitsevägi hakkab; 24-tunnise etteteatamisega ja õppustele kutsuma tajub emakeelekõneleja ebaloomulikuna esimest, sest sellega ei assotsieeru sobivaid kontekste. Küll aga assotsieeruvad emakeelekõnelejal substantiiviga õppus(ed) niisugused kollokatsioonid nagu sõjaline õppus, taktikalised óppused või idioomid ei võtnud õppust, sai õppust, jagab óppust. Kui aga kasutada normikohast sõnajärge Kaitsevägi hakkab õppustele kutsuma vaid 24-tunnise etteteatamisega, siis ei tule esile ühtegi ebaloomulikku bigrammi: hakkab õppustele, Kaitsevägi hakkab, 24-tunnise etteteatamisega ja óppustele kutsuma. Nii esimene kui ka viimane bigramm eeldavad vastastikku teineteist, moodustades semantilis-süntaktilise terviku hakkab óppustele kutsuma, ja emakeelekõneleja tajub seda. Subjektiga algavale sõnajärjepuule omaselt asub adverbiaal ahelverbi komponentide vahel (hakkab õppustele [Lb V main ind pres ps3 sg ps af $<$ FinV $><$ Intr $>$ $<\mathrm{Ad}><\operatorname{Tr}>/ /$ @FMV Ltele S com pl all // @ADVL] ja õppustele kutsuma [Ltele S com pl all // @ADVL Lma V main sup ps ill <NGP-P> // @IMV]), järgneb teine adverbiaal (24-tunnise etteteatamisega).

Siinsed uurimistulemused kinnitavad veel kord, et üks või mitu adverbi verbi paremkontekstis eraldavad tavaliselt analüütiliste vormide 
(mineviku liitajad), analüütiliste sõnade (ühend- ja väljendverbid, tugiverbiühendid, ahelverbid) ning liitpredikaatide (koopula + predikatiiv, verbi finiitvorm + infinitiiv) komponente ehk teisitisõnu - öeldis raamistab verbi laiendeid. Selles positsioonis on tendents koos kasutada seotud määrusi või vabu ja seotud määrusi (vt Sahkai 1999: 27 jj), millest kindlates tekstifunktsioonides moodustub terviküksuseid. Näiteks eitava kõne VDD-struktuuris on kasutatud nii analüütilisi rõhupartikleid kui ka potentsiaalseid liitpartikleid (ei ole ju ka endine, ei ole enam üldse mitte oma, ei ole ka kaugeltki mitte oluline), põhiverb paikneb kas struktuuri alguses või struktuurile järgnevas paremkontekstis $(<$ ta ei $>$ vaielnud kunagi vastu, polnud veel ära <sõitnud $>$ ). Eitava kõne VVDstruktuuri alusel on verbi paremkontekstis kasutatud analüütilisi ühendja väljendverbe (ei pea kaua <vastu>, ei saa päriselt <aru>, ei vaata tagasi, ei lenda ära), mille komponente eraldab reeglipäraselt adverb jne.

Vastupidiselt paremkontekstile soosib verbi vasakkontekst vabade määruste kasutamist. Tegu on peamiselt DDV-struktuuriga (nü̈̈d küll ei, praegu rohkem ei, edaspidi enam ei ja seal all on, nü̈̈ juba on). Harvem esinevad JDV (ent tookord ei, aga nü̈̈d sündis), SDV (padigi justkui torkis) ja VDV (oli järsult keeldunud, oli äsja abiellunud). Lausealgulisi JDV-, DDV- ja DVV-struktuure kasutatakse viiteseose vormistamiseks, DDV-d ka subjektiivmodaalse ja ratsionaalse hinnangu edastamiseks ning rõhuasetuseks, samuti ühendverbide moodustamiseks (päris laht $i$ ei $\langle$ saa $\rangle$, paksult kinni mähitud, kuhugi ära sõita, lihtsalt ümber kirjutada). Vasakkontekstis esineb DSV-struktuuri alusel väljendverbe harva (<oli> ikka puhtust pidanud, <olevat> ka märki tabanud). (Vt Eslon 2014b: 22 jj) Seda toetab ka sõnajärjepuudest leitud teave verbi vasakkonteksti sagedamate järjendite kohta:

Sealsamas@ADVLkõrval@ADVLoli @FMV viljapõld @SUBJ

Aga teel@ADVLkohvikusse@ADVLmõtled @FMVikkagi@ADVL ümber@ADVL

Esimest korda@ADVLsatub@FMV ta@SUBJ silme ette

Oma ukselävel@ADVL seisab@FMV siin@ADVLvalge põllega@ ADVLlihakaupleja@SUBJ 
Siis@ADVL nad @SUBJ tulevad@FMV koos@ADVL alla@ADVL

Nad@OBJ tunneb@FMV siin@ADVL kohe ära

(Matsak jt 2010: 71-72, 75-79)

Niisiis on adverbiliste struktuuride tekstikasutus verbi vasakkontekstis seotud vabade määruslike laienditega, neid rakendatakse viiteseose ja hinnangute vormistamiseks, vähemal määral analüütiliste ühendverbide moodustamiseks, samas kui paremkonteksti kahe seotud või seotud ja vaba määrusliku laiendi alusel kujunevad erinevat liiki analüütilised terviküksused.

Nii verbist vasakul kui ka paremal suhestuvad omavahel struktuuri sõnajärg ja komponentide tekstifunktsioonid, mis tagab teksti sidususe, esituslaadi sujuvuse ja terviklikkuse, mõjutab adressaati, lisab hinnanguid (pragmaatilised tähendused, ekspressiivsed varjundid, modaalsed ja ratsionaalsed hinnangud), varieerib lause infostruktuuri. Samas pole korpusest leitud mustrite sõnaliigijärjendid otseselt tingitud ei (osa) lause süntaksist ega infostruktuurist. Nende tekstifunktsioonid tulenevad järjendi positsioonist verbi kui lause predikatiivse keskme suhtes (vasak- või paremkontekst), mustrite morfosüntaktilise ja leksikaalsemantilise varieerumise piiridest-piirangutest, lekseemide ja vormide kombineerimise reeglitest.

\section{Milliseid tendentse esineb mustrite kinnistumisel?}

Verbi paremkonteksti mustrite kinnistumistendentsid tuginevad adverbi sisaldavate ja adverbita struktuuride vastandusele. Analüüsi tulemused näitavad, et adverbi sisaldavates struktuurides kujuneb nii ainult seotud kui ka vabadest ja seotud laienditest semantilis-süntaktilisi (liitseid leksikaalgrammatilisi) üksuseid: analüütilisi partikleid (nt ju ja $k a$ tõmbumine semantilis-süntaktiliseks ja fonoloogiliseks tervikuks ei ole ju ka endine), sidendeid (nt rinnastav-alistavad rühmsidendid mitte ainult (enam üldse / nii palju) .., vaid (kui) möönduse väljendamisel), vorme (nt mineviku liitaja vormid), analüütilisi sõnu (nt liitsõnad, ühendverbid) ja analüütilisi konstruktsioone (nt ahelverbid, liitsed verbitarindid). 
Adverbita struktuure seevastu iseloomustab kollokatiivsus ja idiomaatilisus (ähmane lootuskiir, tavatu küsimus; must auk, terav keel). Tegu on keelekasutusele iseloomulike tendentsidega: esimene peegeldab aglutinatiivse keelemudeli põhimõtet - tüve- ja abimorfeemide või lekseemide liitumist vormi- ja sõnamoodustuses ning tuletuses -, teine tendents on seotud mitmesõnaliste üksuste semantiliste piirangutega. Esimesel juhul saab rääkida erinevat päritolu liitumitest: liitvormid ehk analüütilised vormid, liitsõnad ja analüütilised sõnad (sh ühendverbid, harva väljendverbid), analüütilised konstruktsioonid (ahelverbid, liitsed verbitarindid). Teisel juhul saab rääkida semantiliselt sidusatest kollokatiivsetest ja idiomaatilistest üksustest (sh väljendverbid ja tugiverbiühendid). Neid kahte tendentsi ühendavad formaalsed taksonoomilised tunnused, milleks on keelekasutusmustri paiknemine verbi suhtes ja selle struktuur. Kinnistumist mõjutavad ka kõneliik (jaatav/eitav) ning piirangud struktuuri komponentide leksikaalsemantilises, morfosüntaktilises ja funktsionaalses varieerumises.

Analüütilisuse tendents paistab kujunevat süntaksi ja semantika piirinähtusena. Eristatakse liitseid tekstilisi üksusi ja sõnastikuüksusi, kusjuures mõlemal juhul on liitsete üksuste ehk liitumite aluseks metafoorsete või metonüümsete seoste põhjal tekkinud tähendusnihe (nt Õim, K. 2006; Õim, H. 2006), millega kaasnevad funktsionaalsemantilised nihked sõnaliikide piiritlemisel. See on oluline mitte pelgalt teooria, vaid ka keeletehnoloogiliste rakenduste (vt Kaalep 1999: 21 jj; Habicht jt 2011) ja keeleõppe seisukohalt (nt Allkivi 2016a; 2016b; Eslon 2014a).

Sõnavormide kasutuses esineb nii kinnistunud kui ka varieeruva struktuuriga mitmesõnalisi üksuseid. Esimesed on semantiliselt ühtsed kompositsioonilised, idiomaatilised ja kollokatiivsed üksused, neil on kas otse- või ülekantud tähendus (nt istub käed rüpes) või ainult ülekantud tähendus (on toss väljas, küll viskab villast), nende aluseks on (mitte)metafoorsed seosed kahe erineva mõistepiirkonna vahel (vt Õim, K. 2014).

Teist liiki mitmesõnalised üksused ilmnevad tekstisageduse alusel ning neil võib olla a) sama referentsiaalne seos tähistatavaga, piiratud morfosüntaktiline, leksikaalne ja sünonüümne varieerumine, kuid 
erinevad pragmaatilised varjundid (nt arutasime seda küsimust, küsimus on arutatud, küsimust sai/saab arutatud; küsimusega on tegeletud, küsimusega sai/saab tegeletud), või b) erinevad referentsiaalsed seosed tähistatavaga, kuid samalaadsed struktuurid võivad olla kinnistunud idiomaatiliselt ja kollokatiivselt (nt võorras veri; särav hõbekett, päästev telefonihelin), olla väljendverbid, mida kasutatakse adverbita pronoomenit sisaldava struktuuriga (tegi ta järelduse, tegi ta ettepaneku, tegi ta otsuse) jm.

Kirjeldatud kahte liiki analüütilisi struktuure ei ole võimalik omavahel võrrelda ega seletada vastandmõistetega sünteetiline/analüütiline või konkreetne/abstraktne, sest ei saa üheselt väita, nagu oleksid analüütilised üksused tähenduselt konkreetsemad kui sünteetilised. Küll aga saab rääkida struktuuri sõnaliigijärjendist, tekstisagedusest, (sünonüümsest) varieerumisest ja kinnistumisest verbist paremal või vasakul kas otse- või ülekantud tähenduses (vt Eslon \& Paeoja 2015: 96-100). Niisuguse taksonoomilise eristuse lingvistiliseks aluseks on semantika ja süntaksi koosmõju tekstilistes analüütilistes terviküksustes. Siinse analüüsi tulemused toetavad seda seisukohta.

Sama referentsiaalne seos tähistatavaga on aluseks VDD-struktuuris rõhumäärsõna ja märusliku laiendi tõmbumisel semantilissüntaktiliseks ning fonoloogiliseks tervikuks (vt 1.1.1, 1.1.2, 1.1.3). Rõhumäärsõnad jälle, veel, vaid, niivõrd, üha, liiga tõmbuvad järgneva määrusliku laiendiga, kirjeldades tegevust, selle toimumise viisi, laadi ja määra (oli jälle kord <ennast tõestanud>, <ta $>$ hoikas veel kord, oli vaid veidi <eemale läinud>, oli niivorrd hästi <ette valmistatud, et>, <auto> kihutas üha kiiremini). Rõhupartiklite ju ja ka tõmbumine rõhumäärsõnaga võimaldab väljendada erinevaid subjektiivmodaalseid ja pragmaatilisi tähendusi (põhineb ju vist, on ju ainult <kooliealised>, saab ka varem/hiljem <tulla>, tuleb ehk ka). Korduvalt kasutatud rõhumäärsõnad ju, $k a(h)$, juba, veel, kord, just, ikka, siiski koos järgneva subjektiivmodaalse hinnangusõnaga, nagu tõesti, täiesti, peaaegu, vist, võib-olla, mõõdavad kõnesoleva tõeväärtust (on ju/vist tõesti, on juba päris). 
Tegu on piiratud hulga adverbide sageda kooskasutusega, mis loob eeldused struktuuri leksikaalgrammatiliseks kinnistumiseks ning on aluseks potentsiaalsete liitadverbide kujunemisele. Grammatiseerunud rõhumäärsõnad moodustavad järgnevate määrustega semantilis-süntaktilisi ja fonoloogilisi terviküksuseid, millest teatud tingimustel reanalüüsi tulemusel võivad kujuneda uued liitsed leksikaalsed üksused, nt veel kord $>$ veelkord, veel mitte $\sim$ mitte veel $>$ veelmitte $\sim$ mitteveel, enam üldse > enamüldse. See võimalus on VDD-struktuuri alusel verbi paremkontekstis avatud ${ }^{3}$.

Mõned kinnistunud modaal- ja rõhupartiklite kombinatsioonid sulanduvad VDD alusel analüütilisteks liitpartikliteks, nt tuleb ehk ka, põhineb ju vist. Kõige sagedamini esinevad selles funktsioonis kaks adverbikooslust - enam üldse ja ka kaugeltki (mitte), nt ei olnud enam üldse huvitatud, ei laienenud ka kaugeltki kõigile osalistele. Eriti selgelt ilmneb kirjeldatud nähtus VDD eitava kõne struktuuris, kus tõmbuvad kaks rõhupartiklit, nt ei ole ju ka, pole üldse mitte. Analoogia põhjal laieneb see tendents ka rõhupartikli ja määruse kooskasutusele, nt pole juba ammu, <ei> kao ka siis/veel/enam/ikka/küll/ka + mitte). Kinnistunud mustris abiverb olema COND:PRES:SG:3 + partiklid ka/ju/juba + adverbiaal äärepealt moodustavad partiklid järgneva määrusega terviküksuse, nt oleks juba äärepealt <käe sirutanud $>$. Niisiis kinnistuvad mõned sageli kasutatud adverbikooslused, mille alusel võivad kujuneda liitpartiklid. Mis suunas kirjeldatud tekstiliste üksuste areng kulgeb, on keeruline oletada, kuna nähtust saab vaadelda üldise grammatisatsiooniprotsessi osana.

VDD-struktuuri eitava kõne mustrite seas eristusid ka niisugused, mille alusel kujuneb eesti keelele omaseid analüütilisi rühmsidendeid nagu mitte ainult .. vaid ka, enam üldse .. vaid, mitte nii palju .. kui;

\footnotetext{
3 Emakeele Seltsi keeletoimkonna otsusega 11. juunist 2012 on lubatud "nii senise normingu kohast lahkukirjutust kui ka sõnaühendite sulandumise ja liitmäärsõnade tekkega põhjendatud kokkukirjutust" (kas või kasvõi, just nagu justnagu, just nimelt $\sim$ justnimelt, kui tahes $\sim$ kuitahes, mis tahes $\sim$ mistahes ja võib-olla $\sim$ võibolla), vt http:// www.emakeeleselts.ee/otsused/ES-keeletoimkond_Muutumatud-s6nad-kokku-lahkukirj-11.06.12.pdf (1.3.2017). Analoogsed juhtumid on levinud kooliõpilaste keelekasutuses, neid on määratletud kõnekeelsuse ilminguna (vt Kukk 2010: 44-47, 94-97).
} 
polnud küll kunagi .. aga/kuid/ent, polnud küll päriselt .. aga/kuid/ent jt. Need kuuluvad vastandava rinnastuse mitte $X$, vaid $Y$ rühmsidendite alla ja sisaldavad kohustuslikku, päritolult adverbilist semantilis-süntaktilist komponenti (korrelaati), millel on samal ajal nii grammatiline, osalauseid siduv kui ka rõhufunktsioon (vt 1.1.3). Tegu on möönduse väljendamiseks kasutatud rinnastuse-alistuse piirjuhtumiga.

Liitumite tekkimist on eesti keeles seletatud grammatisatsiooni ja leksikaliseerumise protsesside osana (nt Jürine 2016; Jürine \& Habicht 2013; Veismann 2009; Habicht \& Penjam 2007; Õim, K. 2006; Metslang 1994), mida toetavad ka eespool kirjeldatud juhtumid (potentsiaalsed liitadverbid, liitpartiklid, analüütilised sidususvahendid). Liitumite kujunemist on peetud keele sisemiseks loomulikuks arenguks (vt Habicht jt 2006), nende kirjeldamiseks on pakutud välja rida semantilisi ja morfosüntaktilisi tunnusjooni (vt Jürine 2016: 290). Liitseid verbitarindeid ja liitvormide kasutust on vaadeldud süntaksikäsitluse all (vt Erelt 1985; EKG II). Helle Metslang on varem märkinud, et "eesti keel moodustab koos liivi ja lapi keelega soome-ugri keelte seas flekteeruvusse kalduva erandrühma, millega kaasneb suurem analüütilisus, märk järgmisest, isoleeriva keele etapist" (Metslang 1994: 10).

Siinsed uurimistulemused näitavad, et leksikaalsemantiliselt, morfosüntaktiliselt ja funktsionaalselt kinnistunud adverbi sisaldavad mustrid verbist paremal on valmis liitadverbide ja liitpartiklite kujunemiseks ning rinnastav-alistavate rühmsidendite laienemiseks (korrelatiivne seos). Analüütiliste konstruktsioonide (ahelverbid, liitsed verbitarindid) ja vormide (mineviku liitajad, abiverbist ja öeldistäitest koosnev lihtöeldis) iseärasus verbist paremal seisneb selles, et nende komponente võivad omavahel lahutada üks või mitu adverbi (vt eespool seos sõnajärjemustritega).

Osa verbi paremkonteksti mustritest iseloomustab see, et neid kasutatakse regulaarselt analüütiliste verbide moodustusmallina, sest sama struktuuri põhjal leksikat varieerides on see võimalus avatud. Ühendverbid (harvem väljendverbid) tulevad verbi paremkontekstis esile peamiselt kolme adverbi sisaldava (VDD, VVD ja VDS) ja väljendverbid kahe 
adverbita struktuuriga (VPS ja VVS). Kõige sagedamini esineb analüütilisi verbe eitava kõne VDD-ga (vt punkt 1.1.3), kus põhiverb eitava kõne lihtminevikus ja olevikus võib paikneda nii struktuuri alguses ja eituspartikkel jääb verbist vasakule (<ta ei > vaielnud kunagi vastu) kui ka struktuuri paremkontekstis (polnud veel ära $<$ sõitnud>, polnudki veel katki <läinud>). Jaatavas kõnes (vt punkt 1.1.2) kasutatakse põhiverbina tavaliselt liikumisverbe minema ja tulema otsetähenduses, harva ka sõitma IMPERF:SG:3 (tuli jälle tagasi, läks peagi laiali, sõitis kuhugile ära), ülekantud tähenduses aga PREs:SG:3 vormis (tuleb vahel ette). Ainukordsed tegevusverbid IMPERF:SG:3 esinevad nii otse- kui ka ülekantud tähenduses (pressis ikka läbi, kü̈̈rutas kähku maha, andis niivorrd järele). Erinevate otsetähenduses kasutatud tajuverbidega PREs:SG:3 moodustub peamiselt ühendverbe (kostab nü̈̈d hästi <ära>, vaatab hoolikalt üle), harva mõni väljendverb (vaatab otsivalt ringi, paistab nüüd juba $<$ kätte>). Kui aga ühendverbi on kasutatud täismineviku liitajavormis, siis seisab abiverbi ja verbipartikli vahel hinnangu-, rõhu- või määrasõna ning põhiverb on verbipartikli järel ( on ju läbi <lugenud>, on salaja maha $<$ maetud $>$, on tublisti edasi $<$ arenenud $>$ ).

Eitava kõne VVD-struktuuri alusel (vt punkt 1.2.2) kasutatud ühendverbide põhiverbiks on tavaliselt tuumverbid saama, andma, tegema, tulema, pidama lihtminevikus (ei saanudki enam <kokku>, ei andnud järele, ei teinud väljagi, ei tulnud välja, ei pidanud vastu); ka eitava kõne oleviku vormis esineb erinevaid otsetähenduses verbe, mille alusel moodustub ühendverbe (ei lenda ära, ei vaata tagasi), harva ka väljendverbe (ei ole võlgu, ei seisa paigal). Siinkohal on oluline märkida, et tegelik väljendverbide esinemus on eitava kõne VVD-struktuuri paremkontekstis siiski avaram, kui trigrammide tasand esile toonud, sest analüütilise verbi komponente võib lahutada nii üks kui ka mitu laiendsõna, nt $e i$ pannud nagu $<$ tähelegi $i$, ei vaadanud mitte sulle $<$ otsa $>$, ei vihtunud seal midagi tantsu (vt eespool sõnajärjemustrite kirjeldus).

VDS-struktuuris (vt punkt 1.3.1) kuuluvad ülekantud tähenduses kasutatud verbid tooma, saama, tulema, tómbama jaatava kõne IMPERF ja PRES:SG:3 vormis koos partitiivse objektiga analüütiliste väljendverbide 
koosseisu, mille komponente lahutab tavaliselt aja- ja viisimäärus (tõil toob endiselt lisa, sai/saab täiesti aru, tõmbas/tõmbab sügavalt (sügavasti) hinge).

Analüüsi tulemused näitasid, et ka adverbita struktuuride alusel esineb vähesel määral väljendverbe: a) VPS (vt punkt 2.1.2) jaatavas kõnes, kus tegema-verbi IMPERF:SG:3 kasutatakse koos substantiiviga SG:GEN vormis - tegi ta järelduse, tegi ta ettepaneku, tegi ta otsuse ning b) VVS (vt punkt 2.2.4) eitavas kõnes, kus saama- ja pidama-modaalverbidele lihtminevikus järgneb substantiiv SG:PART $-<$ nad $>$ ei saanud sõnagi $<$ aru $>$, <me $>$ ei saanud aru, <maja $>$ ei pidanud sooja.

Niisiis on verbi paremkontekstis tekstiliste terviküksuste kujunemisel ilmnenud analüütilisuse tendents seotud kindlat liiki adverbi sisaldavate, harva adverbita struktuuridega, mille funktsionaalne potentsiaal on leksikaalsemantiliselt, morfosüntaktiliselt ja sõnajärje poolest piiratud. Adverbilised komponendid võivad neis tõmbuda liitadverbideks, liitpartikliteks ja liitseteks sidenditeks või moodustada analüütilisi sõnu piiratud leksikaalsemantiliste verbirühmadega. Adverbita struktuuride kinnistumise aluseks on teistsugused põhjused. Mõningal määral puudutab see ka adverbilist VDS-, harva VVD- ja VDD-struktuuri, mille põhjal esineb analüütilisi väljendverbe. Tegu on struktuuri komponentide semantilisest sobivusest tingitud kollokatsiooniliste üksustega või metafoorse ja metonüümse ülekande tulemusel kujunenud idiomaatiliste üksustega, mis pole otseselt analüütilisuse tendentsi väljendus.

\section{Kuidas seletada stereotüüpe?}

Kuna stereotüübi mõistet kasutatakse laialdaselt, siis on mõiste sisu üsna avar (nt Dryer 1996; Kashima jt 2008; Balossi 2014). Siinsed uurimistulemused lubavad mõistet konkretiseerida mitte niivõrd nähtusena, mida põhjustavad struktuuride kinnistumine ja esinemissagedus, vaid nähtusena, mida kujundavad kinnistunud tekstifunktsioonid. Selle seose leidmiseks on Klastrileidjaga teostatud lingvistiline klasteranalüüs olnud sobiv meetod, kuna fikseerib mustrite tüüpilised tekstifunktsioonid, 
võimaldades uurimisobjekti formaliseerida, kategoriseerida ja lingvistiliselt interpreteerida erineval abstraktsioonitasandil.

Mustrite liigitamine ja stereotüüpide esiletoomine tugineb formaalsetele tunnustele: a) struktuuri pikkus (kolm komponenti ehk trigramm); b) positsioon (verbi paremkontekst) - eristuvad morfoloogilised klassid, uurimisobjektiks verbialguline klass; c) verbialgulisse klassi kuuluvate trigrammide viimase komponendi sõnaliigi varieerumine piiritleb morfoloogilisi alamklasse, nt V-D, V-S, V-A jt; d) struktuuri keskmise komponendi sõnaliigi varieerumine toob esile iga alamklassi klastrid, nt V-D alamklassis on neli klastrit - VDD-, VVD-, VSD-, VPD-struktuurid; e) adverbi olemasolu või puudumise põhjal struktuuris jagunevad need adverbi sisaldavateks ja adverbita mustriteks; f) iga klastri leksikaalsemantilise, morfosüntaktilise ja funktsionaalse varieerumise järgi eristuvad ühelt poolt avara/piiratud varieerumisega adverbi sisaldavad ja adverbita mustrid ning teisalt kinnistunud adverbi sisaldavad ja adverbita mustrid. Mõlemal juhul võib kindlates tekstifunktsioonides kasutatud mustritel ilmneda stereotüüpsust, kuid leksikaalgrammatiline kinnistumine ei märgi automaatselt nende stereotüüpsust.

Keelekasutusmustrid kujunevad samalaadsete struktuuride esinemissageduse alusel tekstis ja on väljenduslaadi poolest tavaliselt neutraalsed. Erinevalt mustritest on stereotüüp markeeritud, seotud tekstiga referentsiaalselt, pragmaatiliselt, emotsionaalselt, ekspressiivselt, modaalselt ja idiomaatiliselt (vt Dyer 1996). Nt VDS-struktuuri (vt punkt 1.3.1) iseloomustavad jaatavas ja eitavas kõnes suhteliselt piiratud varieerumisega adverbi-substantiivi kooskasutused, mis võimaldavad a) hinnata ja täpsustada edastatavat sisu (väite tõesuse kinnitamine ja rõhutamine - on tõesti mure, on siiski õigus; negatiivne hinnang - on vaid mõttekuju, on juba proosa; ekspressiivse või subjektiivmodaalse värvingu lisamine - pole enam pääsu 'mittevõimalikkus', pole niipea tulekut 'pole võimalust', 'pole mõtet'), b) hoiatada (soovimatute) tagajärgede eest (<see> on alles algus), c) rääkida millestki möönvalt, vihjamisi (pole ju ema teha) jm. Hakkab silma, et loetletud funktsioonides tuleb regulaarselt esile hinnanguid väljendavaid kollokatiivseid ja idiomaatilisi üksusi, 
mille tekstikasutus on avatud leksikaalgrammatiliste stereotüüpide kujunemiseks (nt oli päris ime, oli alles uni, pole enam pääsu; on alles algus, on alles töö). VDS-struktuuri sõnajärje ja adverbide leksikaalsemantiline varieerimine lisavad esituslaadile kõnekeelsust, emotsionaalsust ning ekspressiivsust.

Leksikaalsemantiliselt ja funktsionaalselt piiratud VDA-struktuuris markeerib adverb adjektiiviga tähistatud tunnuse määra subjektiivsel hinnanguskaalal tõepoolest-muidugi-peaaegu-vist: a) väga, niivõrd, täiesti, üsna 'üleni', pisut; b) väga, eriti, liiga, lausa, küllalt; c) väga, päris, pigem, peaaegu; d) väga, täiesti, täis, peaaegu. lt-lõpuliste adverbidega hinnatakse tunnuse ilmnemise viisi: häirivalt, talumatult, kiuslikult, mänglevalt (vt punkt 1.3.1) jne.

Niisiis pole struktuuri kasutussagedus stereotüüpide kujunemise otsene põhjus. Sagedus on kaasnev asjaolu, mis võib, kuid ei pea soodustama stereotüüpide kujunemist. Ka struktuuri leksikaalsemantilised ja morfosüntaktilised piirangud, samuti ühe morfosüntaktilise kirje domineerimine mustris ehk morfosüntaktilise dominandi olemasolu ei tähista automaatselt stereotüüpsust, ent regulaarsel kasutamisel mingis kindlas tekstifunktsioonis võib niisugune võimalus avaneda. Näiteks VDD-struktuuris, kus on üldistuste sõnastamiseks käibel samalaadsed väljendid on kord juba, on kord jälle ja tuleb kord jälle (elu on kord juba selline, ühiskond on kord juba niimoodi seatud; Islandi tuhk tuleb kord jälle), näitas nende kasutus laienemist koos modaalverbidega (saab (võib, tuleb) kord jälle naerda), vt punkt 1.1.2. Analoogselt adverbikooslusega kord juba (jälle) laieneb jõudsasti ka adverbi enam kasutus koos erinevate täistähenduslike verbidega lihtmineviku, harvem oleviku vormis, nt ei klappinud enam, ei näinud enam, ei tahtnud enam, ei saanud enam ja ei roni enam, ei saa enam. Niisiis on adverbikooslust kord juba (jälle) ja adverbi enam hakatud kasutama stereotüüpselt VVD-struktuuri jaatavas kõnes, eitava kõne leksikaalgrammatiline stereotüüp on $e i$ ole(gi) enam (vt punkt 1.2.2).

VPS-struktuuri komponentide kinnistunud kooskasutus verb IND:IMPERF:SG:3 + demonstratiivpronoomen see (too) SG:NOM + 
SUB:SG:ELA tõi esile ajamäärusliku leksikaalgrammatilise stereotüübi toimus sel aastal, muutus sel ajal, oli sel (tol) päeval, oli sel suvel, mida kasutatakse lause või sellest suuremate tekstilõikude alguses üldlaiendina, et siduda ajaliselt järgnevad sündmused terviklikuks narratiiviks, mis on omane kirjeldavale esituslaadile (vt punkt 2.1.2).

Kinnistunud tekstifunktsiooniga stereotüübi näiteks on ka koordinatiivse seose struktuur VAJ (olema IND:IMPERF:SG:3 koopula funktsioonis + ADJ:SG:NOM predikatiivina + koordinatiivne sidesõna ja), mida kasutatakse tunnuste loendamisel, nt $<$ maa $>$ oli tühi ja $<$ paljas $>$, <nuga $>$ oli terav ja $<$ sile $>$ (vt punkt 2.2.2).

Kuigi struktuuri leksikaalsemantilised ja morfosüntaktilised piirangud ning morfosüntaktilise dominandi olemasolu, nagu eespool viitasin, ei näita automaatselt stereotüüpsust, võivad need soodustada stereotüüpide kujunemist. Mida piiritletum on verbi semantika, nt VSD-struktuuri puhul, kus tavaliselt kasutatakse kõneverbe lausus, vastas, ütles, küsis, õiendas, ja mida kinnistunum on verbi morfosüntaks (VDS-s IND:IMPERF:SG:3 finiitöeldisena), seda selgemad on referentsiaalsed seosed elusa/elutu subjekti vormistamisega SG:NOM, GEN ja ELAT vormides vastavalt subjekti, objekti ja käändelise määruse funktsioonis ning seda piiratum on järgneva adverbi valik (tavaliselt $l t$-lõpuline viisimäärus): lausus Relli ópetlikult (ebamääraselt, lihtsalt, skeptiliselt, tähtsalt, agressiivselt, pahaselt), vt punkt 1.3.2. Analoogselt soodustab stereotüübi kujunemist ka morfosüntaktiline dominant. Näiteks kõneverbide ja personaalpronoomeni lühivormi ta regulaarse kooskasutusega VPD-struktuuris (vt punkt 1.3.3) kaasneb komponentide suhteliselt kitsas leksikaalsemantiline ning morfosüntaktiline varieerumine - kõneverbile IND:IMPERF:SG:3 finiitvormis järgneb reeglina viisimäärusena kasutatud $l t$-lõpuline adverb (vastas ta tõsiselt, küsis ta variserlikult, lausus ta mõtlikult) ning olema IND:IMPERF:SG:3 abiverbi funktsioonis määrab verbi paremkonteksti valikuid (oli ta siin <varemgi käinud>, oli ta veel < vaba ja vallaline>, küsis ta siis $<$ karmilt $>$, lausus ta siis $<$ mõtlikult $>$, oli ta tagasi $<$ tulnud $>$ ).

Ilukirjanduskeele alusel esile tulnud stereotüüpsuse näiteid ei saa pidada taunitavaks. Sõnade ja vormide tüüpiline ning sage kooskasutus 
struktuuris loob võimaluse tekstiliste stereotüüpide kujunemiseks, mida läheb vaja terviklike sidusate tekstide produtseerimiseks. Grammatiliste elementide ja leksika kombineerumine sageli korduvas sõnaliigijärjendis ehk morfoloogilises struktuuris tugineb keeleökonoomia põhimõttele ning juhindub suhtlusvajadustest. Seose tugevus komponentide vahel võib olla erinev - vabadest ühenditest kollokatiivsete ja idiomaatiliste üksusteni. Siinse analüüsi tulemused näitasid, et adverbita struktuuridele on omasem komponentide semantiline ja adverbi sisaldavatele komponentide leksikaalgrammatiline sidusus. Struktuuri kasutus verbist paremal (samuti vasakul) kinnistub kindlates tekstifunktsioonides, mis on stereotüüpide kujunemise aluseks. Komponentide vahel ilmnenud grammatisatsiooni ja leksikaliseerumise tendentsid toovad esile keelekasutuse funktsionaalse potentsiaali, sünonüümse, leksikaalsemantilise ja morfosüntaktilise varieerumise piirid ja piirangud. Struktuuride sõnajärg pole vaba, selle varieerumisel on kindel kommunikatiivne tähendus ja pragmaatilised, subjektiivmodaalsed ning ekspressiivsed varjundid. Struktuuri elementide kooskasutusmustrite esinemissagedus ja stereotüüpsus pole olemuslikult grammatisatsiooni väljendus, vaid tekstisüntaksi nähtus. Keeleline muutus ei pruugi kulgeda kaassõnaühendist semantilise käändeni, grammatilisest käändest määruseni, sihitise määruslikust täiendist genitiivse täiendi ja adjektiveerunud laiendini, vaid jääb harva, kuid stereotüüpselt kasutatud tekstimustriks, mille abil tähistatakse nt esemete või asjade paiknemist ruumis ja nähtuste kulgemist ajas (vt punkt 2.2.1).

Siinsed uurimistulemused on rakendatavad eesti keele kasutusgrammatika reeglite kirjeldamiseks, neist tõuseb tulu nii keeletehnoloogilistes kui keeleõppe eesmärgil loodud rakendustes. Keeleõppe seisukohalt oleks mõttekas lähtuda erinevate suhtlusvajaduste puhul olulistest mustritest ja nende sõnaliigijärjenditest, omandada mustrite tekstifunktsioonid, komponentite leksikaalgrammatilise varieerumise piirangud ning piirid, tunnetada nende kasutuses võimalikke pragmaatilisi, subjektiivmodaalseid ja ekspressiivseid tähendusvarjundeid, õppida kasutama kollokatiivselt ja idiomaatiliselt kinnistunud struktuure, mõistma 
analüütiliste üksuste tekkemehhanismi ja seda analoogia põhjal rakendama, tunda analüütiliste üksuste reeglipärast sõnajärge tekstis jm. See eeldab, et eesti keele õpe tugineks uurimispõhisele tasemeõppe mudelile, mille alusel on võimalik luua kontseptuaalselt sidus õpikute ja sõnastike seeria.

\section{Lühendid}

$\begin{array}{llll}\text { ADJ } & \text { adjektiiv } & \mathrm{A} & \text { adjektiiv } \\ \text { ADV } & \text { adverbiaal } & \mathrm{D} & \text { adverb } \\ \text { ELA } & \text { elatiiv } & \mathrm{J} & \text { konjunktsioon } \\ \text { GEN } & \text { genitiiv } & \mathrm{K} & \text { adpositsioon } \\ \text { IMPERF } & \text { imperfekt } & \mathrm{N} & \text { numeraal } \\ \text { IND } & \text { indikatiiv } & \mathrm{P} & \text { pronoomen } \\ \text { INF } & \text { infinitiiv } & \mathrm{S} & \text { substantiiv } \\ \text { NEG } & \text { negatiiv } & \mathrm{V} & \text { verb } \\ \text { NOM } & \text { nomintatiiv } & & \\ \text { PL } & \text { plural } & & \\ \text { PRES } & \text { preesens } & & \\ \text { SG } & \text { singular } & & \\ \text { SUB } & \text { substantiiv } & & \end{array}$

\section{Kirjandus}

Allkivi, Kais 2016a. C1-tasemega eesti keele õppijate kirjalik keelekasutus võrdluses emakeelekõnelejatega: samalaadsusi ja nihkeid verbist paremal paiknevas kontekstis ['Written language use of C1 learners of Estonian and native speakers in comparison: Similarities and differences in verb-initial fourgrams']. Magistritöö. Tallinn: Tallinna Ülikool.

Allkivi, Kais 2016b. C1-tasemega eesti keele õppijate ja emakeelekõnelejate kirjaliku keelekasutuse võrdlus verbialguliste tetragrammide näitel ['Written language use of $\mathrm{C} 1$ learners of Estonian and native speakers in comparison: Analysis of verb-initial fourgrams']. - Lähivõrdlusi. Lähivertailuja 26, 54-83. https://doi.org/10.5128/LV26.02

Balossi, Giuseppina 2014. A Corpus Linguistic Approach to Literary Language and Characterization: Virginia Woolf's The Waves. Linguistic Approaches to Literature 18. Amsterdam, Philadelphia: John Benjamins Publ. Co. 
Dryer, Richard 1996. The role of stereotypes. - Paul Marris, Sue Thornham (Eds.), Media Studies: A Reader. 2nd Edition. Edinburgh: Edinburgh University Press, 245-251.

Ehala, Martin 2001. Eesti keele baassõnajärjest ['Basic word order of Estonian']. Reet Kasik (Toim.), Keele kannul: pühendusteos Mati Erelti 60. sünnipäevaks 12. märtsil 2001. Tartu Ülikooli eesti keele õppetooli toimetised 17. Tartu: Tartu Ülikooli Kirjastus, 24-41.

EKG II = Erelt, Mati, Reet Kasik, Helle Metslang, Henno Rajandi, Kristiina Ross, Henn Saari, Kaja Tael, Silvi Vare 1993. Eesti keele grammatika II ['Grammar of Estonian language II']. Tallinn: Eesti TA Keele ja Kirjanduse Instituut.

Erelt, Mati 1985. ma-, mas- ja mast-infinitiivist eesti keeles ['About ma-, mas- and mast-infinitives in Estonian']. - Ars Grammatica 1985. Tallinn: Valgus, $4-22$.

Eslon, Pille 2013. Kahe keelekasutusvariandi võrdlus: morfoloogilised klassid ja klastrid ['The comparative study of language use: Morphological classes and clusters']. - Lähivõrdlusi. Lähivertailuja 23, 13-38. https://doi. org/10.5128/LV23.01

Eslon, Pille 2014a. Morfosüntaktilise ja leksikaalse varieerumise piiridest: ilukirjandus- ja õppijakeele kasutusmustrite vorrdlus ['On the textual functions of adverbial structures in literary Estonian and Estonian learner language']. - Eesti Rakenduslingvistika Ühingu aastaraamat 10, 55-71. https:// doi.org/10.5128/ERYa10.04

Eslon, Pille 2014b. Adverbi sisaldavate struktuuride tekstifunktsioonidest eesti ilukirjandus- ja õppijakeeles ['Constraints on morphosyntactic and lexical variability’]. - Lähivõrdlusi. Lähivertailuja 24, 15-46. https://doi. org/10.5128/LV24.01

Eslon, Pille, Heleriin Paeoja 2015. Samatähenduslike sünteetiliste ja analüütiliste verbide kasutamine ['Use of the synonymous synthetic and analytical verbs']. - Lähivõrdlusi. Lähivertailuja 25, 63-104. https://doi.org/10.5128/ LV25.04

Habicht, Külli, Leelo Keevallik, Ilona Tragel 2006. Keele muutumine kasutuskontekstis ['Sprachänderung im Kontext des Sprachgebrauchs']. - Keel ja Kirjandus 8, 609-625.

Habicht, Külli, Pille Penjam 2007. Kaassõna keeleuurija ja -kasutaja käsituses ['Adpositions as viewed by a linguist and by a language user']. - Emakeele Seltsi aastaraamat 52 (2006), 51-68.

Habicht, Külli, Pille Penjam, Külli Prillop 2011. Sõnaliik kui rakenduslik ja lingvistiline probleem: sõnaliikide märgendamine vana kirjakeele korpuses ['Part 
of speech as a functional and linguistic problem: Annotation of parts of speech in the corpus of old written Estonian']. - Eesti Rakenduslingvistika Ühingu aastaraamat 7, 19-41. https://doi.org/10.5128/ERYa7.02

Jürine, Anni 2016. The development of complex postpositions in Estonian: A case of grammaticalization and lexicalization. Dissertationes Philologiae Estonicae Universitatis Tartuensis 38. Tartu: University of Tartu Press.

Jürine, Anni, Külli Habicht 2013. Kaassõnade tsükliline areng ['The cycle of postpositions']. - Keel ja Kirjandus 12, 736-749.

Kaalep, Heiki-Jaan 1999. Eesti keele ressursside loomine ja kasutamine keeletehnoloogilises arendustöös ['Development of the Estonian Language Technology Resources and Their Usage in Computational Linguistics']. Dissertationes philologiae estonicae Universitatis Tartuensis 7. Tartu: TÜ Kirjastus.

Kaivapalu, Annekatrin 2010. Mõnede eesti sõnajärjemallide psühholingvistilisest reaalsusest ['On psycholinguistic reality of some word order patterns of Estonian']. - Eesti Rakenduslingvistika Ühingu aastaraamat 6, 103-120. http://dx.doi.org/10.5128/ERYa6.07

Kashima, Yoshihisa, Klaus Fiedler, Peter Freytag (Eds.) 2008. Stereotype Dynamics. Language-Based Approaches to the Formation, Maintenance, and Transformation of Stereotypes. New York, London: Lawrence Erlbaum Associates.

Kukk, Inga 2010. Kõnekeelsus õpilaskirjandites ['Colloquial language in students compositions']. Magistritöö. Tartu Ülikool.

Lindström, Liina 2005. Finiitverbi asend lauses. Sõnajärg ja seda mõjutavad tegurid suulises eesti keeles ['The position of the finite verb in a clause: Word order and the factors affecting it in spoken Estonian']. Dissertationes philologiae estonicae Universitatis Tartuensis 16. Tartu: Tartu Ülikooli Kirjastus.

Matsak, Erika, Pille Eslon, Jaagup Kippar 2010. Eesti keele sõnajärje vealeidja prototüübi arendamine ['The development of the prototype for an automatic word order error detector for the Estonian language']. - Pille Eslon, Katre Õim (Toim.), Korpusuuring ja meetodid. Tallinna Ülikooli eesti keele ja kultuuri instituudi toimetised 12. Tallinn: TLÜ EKKI, 59-100.

Metslang, Helena, Erika Matsak 2010. Kesksete lausekomponentide järjestus õppijakeeles: arvutianalüüsi katse ['Automatic word order analysis of Estonian as a second language: The nuclear sentence']. - Eesti Rakenduslingvistika Ühingu aastaraamat 6, 175-193. http://dx.doi.org/10.5128/ERYa6.11

Metslang, Helle 1994. Grammatiseerumisest eesti ja soome keeles ['About grammaticalization in Estonian and Finnish language']. - Lähivertailuja 7. 
Turun yliopiston suomalaisen ja yleisen kielitieteen kaitoksen julkaisuja 44. Turku: Turun yliopisto, 9-32.

Ogren, David 2015. Sõnajärg, infostruktuur ja objekti kääne ['Word order, information structure and object case in Estonian']. - ESUKA 6 (3), 197-213. https://doi.org/10.12697/jeful.2015.6.3.08

Remmel, Nikolai 1963. Sõnajärjestus eesti lauses. Deskriptiivne käsitlus ['Word order of the Estonian clauses. A descriptive treatment']. - Eesti keele süntaksi küsimusi. Tallinn: Eesti Riiklik Kirjastus, 216-271.

Rätsep, Huno 1978. Eesti keele lihtlause tüübid ['Typology of simple sentences in Estonian']. Tallinn: Valgus.

Sahkai, Heete 1999. Eesti verbifraasi sõnajärg ['Word order of the Estonian verb phrases']. - Keel ja Kirjandus 1, 24-32.

Tael, Kaja 1988. Sõnajärjemallid eesti keeles (võrrelduna soome keelega) ['Estonian word order patterns (in comparison with Finnish language)']. Tallinn: TA Keele ja Kirjanduse Instituut.

Trainis, Jekaterina 2015. Linguistic cluster analysis: A method for describing language units and indicating regularities in language. - Wojciech Malec, Marietta Rusinek (Eds.), Within Language, Beyond Theories. Vol. III. Discourse Analysis, Pragmatics and Corpus-Based Studies. Cambridge Scholars Publishing, 229-243.

Trainis, Jekaterina, Kais Allkivi 2014. Ilukirjanduskeelest uue pilguga ['On belletristic language from a new perspective']. - Eesti Rakenduslingvistika Ühingu aastaraamat 10, 283-306. https://doi.org/10.5128/ERYa10.18

Veismann, Ann 2009. Eesti keele kaas- ja määrsõnade semantika võimalusi ['Semantics of Estonian adpositions and adverbs']. Dissertationes linguisticae Universitatis Tartuensis 11. Tartu: Tartu Ülikooli Kirjastus.

Õim, Haldur 2006. Aeg ja inimesed: mida aeg võib meiega teha ja mida meie ajaga ['The time and the human being: What can do time with as and we with time']. - Ellen Niit (Toim.), Keele ehe. Tartu Ülikooli eesti keele õppetooli toimetised 30. Tartu: Tartu Ülikool, 223-231.

Õim, Katre 2006. Käändevormide adverbialiseerumisest ['About adverbialization of case forms in Estonian']. - Ellen Niit (Toim.), Keele ehe. Tartu Ülikooli eesti keele õppetooli toimetised 30. Tartu: Tartu Ülikool, 232-248.

Õim, Katre 2014. Metafoorsete sõnaühendite automaatse tuvastamise probleeme ['Some problems of multiword expressions automatic recognition']. - Ettekanne Eesti Kognitiivse Keeleteaduse Ühingu 3. aastakonverentsil Tartus 4. aprillil 2014. Ettekande slaidid. 


\title{
Patterns of language use found on the right periphery of the verb: Morphosyntactic and lexico-semantic variability
}

\author{
PILLE ESLON \\ Tallinn University
}

The article discusses the patterns of language use of the Estonian literary language found on the right periphery of the verb. The discussion focuses on threecomponent structures both including and not including an adverb. On the basis of structures including an adverb both free and bound, or only just bound modifiers will joint to form lexico-grammatical units - analytical particles (e.g. $j u$ and $k a$ will gravitate together to form a semantic-syntactic and phonological whole ei ole ju ka endine), conjunctions (e.g. co-ordinating - correlative compound conjunction mitte ainult (enam üldse, nii palju) .., vaid (kui) expressing concession), patterns (e.g. compound past tense forms), analytical expressions (e.g. compound words, phrasal verbs) and analytical constructions (e.g. compound verbs and verb syntagms). The patterns not including an adverb are characterised by collocations and idiomaticity (e.g. terane tüdruk, võóras veri, also idiomatic expressions). These exemplify two tendencies characteristic of the use of the Estonian language: the former reflecting the principle of the agglutinative model - joining of morphemes and lexemes (processes linked to grammatisation and lexicalising), the latter showing lexicosemantic restrictions in the formation of multi-word units. The patterns of the right periphery context of the verb have specific textual functions, which are based on the morphosyntactic and lexico-semantic restrictions of the fixed word-order structures. The actual links between the structural components, or the rules of use, are the narrower the freer language functioning is perceived to be. From this point of view, the patters containing an adverb and analytical units play an important part in the regulation of the so-called free word order of the Estonian language and in text generation. Once the patterns are stablished in a particular text function, 
components of those structures can be used as stereotypes and to form new stereotypes (e.g. toimus sel aastal, oli sel suvel; on kord juba, tuleb kord jälle).

Keywords: semantics; morphosyntax; patterns of language use; the Estonian language

\section{Pille Eslon}

Tallinna Ülikooli digitehnoloogiate instituut Narva mnt 29, 10120 Tallinn, Estonia peslon@tlu.ee 